\title{
Increase in aflatoxins due to Aspergillus section Flavi multiplication during the aerobic deterioration of corn silage treated with different bacteria inocula
}

\author{
Francesco Ferrero, ${ }^{1}$ Simona Prencipe, ${ }^{1}$ Davide Spadaro, ${ }^{1,2}$ Maria Lodovica Gullino, ${ }^{1,2}$ Laura Cavallarin, ${ }^{3}$ \\ Serenella Piano, ${ }^{1}$ Ernesto Tabacco, ${ }^{1}$ and Giorgio Borreani ${ }^{1 *}$ \\ ${ }^{1}$ Department of Agricultural, Forest and Food Sciences (DISAFA), University of Torino, Largo Braccini 2, 10095 Grugliasco (Turin), Italy \\ ${ }^{2}$ Centre of Competence for Innovation in the Agro-environmental Sector (AGROINNOVA), University of Torino, Largo Braccini 2, \\ 10095 Grugliasco (Turin), Italy \\ ${ }^{3}$ Istituto di Scienze delle Produzioni Alimentari (ISPA), Consiglio Nazionale delle Ricerche, Largo Braccini 2, 10095 Grugliasco (Turin), Italy
}

\section{ABSTRACT}

The growth of Aspergillus flavus and the production of aflatoxins (AF) during the aerobic deterioration of corn silage represent a problem for animal and human health. This experiment was conducted to evaluate whether the presence of $A$. flavus and AF production originate from the field or additional AF are produced during the fermentation phase or during aerobic deterioration of corn silage. The trial was carried out in northern Italy on corn at a dry matter (DM) level of $34 \%$. The fresh herbage was either not treated (C) or treated with a Lactobacillus buchneri (LB) NCIMB $40788\left[\left(\right.\right.$ at $3 \times 10^{5} \mathrm{cfu} / \mathrm{g}$ of fresh matter $\left.(\mathrm{FM})\right]$, Lactobacillus hilgardii $(\mathrm{LH})$ CNCM I-4785 (at $3 \times 10^{5}$ $\mathrm{cfu} / \mathrm{g}$ of $\mathrm{FM}$ ), or their combination (LB+LH; at 1.5 $\times 10^{5} \mathrm{cfu} / \mathrm{g}$ of FM of each strain) ensiled in 20-L silos and opened after $250 \mathrm{~d}$ of ensiling. After silo opening, the aerobic stability was evaluated and samples were taken after 7 and $14 \mathrm{~d}$ of air exposure. The pre-ensiled material, the silages at silo opening, and the aerobically exposed silages were analyzed for DM content, fermentative profiles, microbial count, nutritive characteristics, $\mathrm{DM}$ losses, and $\mathrm{AFB}_{1}, \mathrm{AFB}_{2}, \mathrm{AFG}_{1}$, and $\mathrm{AFG}_{2}$ contents. Furthermore, a subsample of colonies with macromorphological features of Aspergillus section Flavi was selected for AF gene pattern characterization and in vitro AF production. The presence of $A$. flavus was below the detection limit $\left(<1.00 \log _{10} \mathrm{cfu} / \mathrm{g}\right)$ in the fresh forage before ensiling, whereas it was found in 1 out of 16 silage samples at silo opening at a level of 1.24 $\log _{10} \mathrm{cfu} / \mathrm{g}$. The AF were found in both the fresh forage and at opening in all the samples, with a predominance of $\mathrm{AFB}_{2}$ (mean value of $1.71 \mu \mathrm{g} / \mathrm{kg}$ of $\mathrm{DM}$ ). The inocu-

Received July 30, 2018.

Accepted October 15, 2018.

*Corresponding author: giorgio.borreani@unito.it lation of lactic acid bacteria determined a reduction in the lactic-to-acetic ratio compared with the control. A larger amount of acetic acid resulted in a lower yeast count and higher aerobic stability in the treated silages than in the control ones. At the beginning of aerobic deterioration, the yeasts increased to over $5 \log _{10} \mathrm{cfu} / \mathrm{g}$, whereas the molds were close to the value observed at silo opening. When the inhibiting conditions were depleted ( $\mathrm{pH}$ and temperature higher than 5 and $35^{\circ} \mathrm{C}$, respectively), both the total molds and A. flavus reached higher values than 8.00 and $4.00 \log _{10} \mathrm{cfu} / \mathrm{g}$, respectively, thus determining the ex novo production of $\mathrm{AFB}_{1}$ during aerobic deterioration, regardless of treatments. The analysis of gene pattern showed that $64 \%$ of the selected colonies of A. flavus showed the presence of all $4 \mathrm{AF}$ gene patterns, and $43 \%$ of the selected colonies were able to produce AF in vitro. During air exposure, after $1,000^{\circ} \mathrm{C} \cdot \mathrm{h}$ have been cumulated, starch content decreased (below 10\% DM) and concentration of neutral detergent fiber, acid detergent fiber, hemicelluloses, crude protein, and ash increased. The inoculation with $\mathrm{LB}$ and $\mathrm{LB}+\mathrm{LH}$ increased the aerobic stability of the silages and delayed the onset of aerobic microbial degradation, which in turn indirectly reduced the risk of $A$. flavus outgrowth and $\mathrm{AFB}_{1}$ production after silage opening.

Key words: aerobic deterioration, aflatoxin, mycotoxins, silage, fermentation quality

\section{INTRODUCTION}

Producing high-quality and microbiologically safe silage while avoiding DM losses as much as possible is a challenge for any livestock producer (Borreani et al., 2018). Aerobic deterioration increases DM losses, reduces the nutritive value of silage, and increases risks to animal and human health due to the growth of pathogenic microorganisms and production of endotoxins and mycotoxins (Pahlow et al., 2003). Mycotoxins are secondary metabolites with low molecular weight 
that are mainly produced by fungi belonging to the $A s$ pergillus, Penicillium, Fusarium, and Alternaria genera (Keller et al., 2013). Mold and mycotoxin contamination of several feed and forages represent an important problem for human and animal health (Driehuis, 2013; Spadaro et al., 2015). Furthermore, this contamination causes increases in food production costs as a result of the increased need for testing, lower prices received for contaminated loads, potential lawsuits from consumers, and decreased livestock performance (Mitchell et al., 2016). Only a few of the detected mycotoxins in the milk supply chain are responsible for significant changes in food safety, and among these the most harmful are aflatoxins (AF; Murphy et al., 2006). Aflatoxins can be produced by such species of Aspergillus section Flavi as A. flavus and A. parasiticus (Varga et al., 2011). The potential ability of $A$. flavus strains to produce AF has been analyzed in several studies; for example, through the analysis of the production of sclerotia and the presence of aflatoxin biosynthesis gene pathways and the in vitro production of AF (Cotty, 1989; Abbas et al., 2005; Criseo et al., 2008). The incidence of toxigenic A. flavus from different matrices has been found to range from 50 to 70\% (Nesci and Etcheverry, 2002; Mauro et al., 2013; Prencipe et al., 2018).

The AF that occur naturally are aflatoxin $B_{1}$ $\left(\mathbf{A F B}_{\mathbf{1}}\right), \mathrm{G}_{1}\left(\mathbf{A} \mathbf{F} \mathbf{G}_{1}\right)$, and their dihydro derivatives $\mathrm{B}_{2}$ $\left(\mathbf{A F B} \mathbf{B}_{2}\right)$ and $\mathrm{G}_{2}\left(\mathbf{A F G}_{2}\right)$. Aflatoxin $\mathrm{B}_{1}$ is the most toxic and carcinogenic (IRAC, 2012), and when it is ingested through contaminated rations to lactating animals it is in part hydroxylated in the liver to aflatoxin $\mathrm{M}_{1}$ $\left(\mathbf{A F M} \mathbf{M}_{1}\right)$. Aflatoxin $\mathrm{M}_{1}$ appears in milk within $12 \mathrm{~h}$ from ingestion, with a mean carryover of around 3.5\% (Veldman et al., 1992). The World Health Organization (WHO, 2002) evaluated the 2 maximum concentrations of aflatoxin $\mathrm{M}_{1}$ that had been proposed by the Codex Committee on Food Additives and Contaminants, 50 and $500 \mathrm{ng} / \mathrm{kg}$ (for the European Union and United States, respectively), and concluded that, based on worst-case assumptions, the projected risk of liver cancer attributable to $\mathrm{AFM}_{1}$ would be very small if either of these maximum levels were implemented. To reduce the risk of $\mathrm{AFM}_{1}$ contamination, the daily ingestion of $\mathrm{AFB}_{1}$ should be limited to 40 and $400 \mu \mathrm{g} /$ cow per day for the European Union and the United States, respectively (Veldman et al., 1992). Corn silage is the main source of AF in warm regions (i.e., southwestern United States), whereas in temperate region corn is generally less contaminated than other feeds (e.g., corn grain, peanuts, and cottonseed). However, the large use of corn silage on dairy farms throughout the world imposes the need for a careful management of the factors that could increase $\mathrm{AFB}_{1}$ contamination in the field or during silage conservation.
Aflatoxins in corn silage can be derived from both the field and produced ex novo during aerobic deterioration (Garon et al., 2006; González-Pereyra et al., 2008; Cavallarin et al., 2011). The preharvest contamination of corn crops is well known and has been studied and reviewed by Guo et al. (2008), whereas very few studies have analyzed the postharvest contamination of corn silage for several reasons; for example, the difficulties of recovering AF in the silage matrix (Garon et al., 2006; Cavallarin et al., 2011), the possible increase in concentration of $\mathrm{AF}$ due to DM losses during conservation or the feed-out phase, the possible ex novo production by Aspergillus during ensiling or the feed-out phase, and the possible degradation or detoxification by lactic acid bacteria (Ahlberg et al., 2015). Furthermore, it is not easy to separate the pre- and postharvest fungal contamination of whole corn silage, and only a few unclear indications have been reported in literature (Lacey, 1989).

Inoculation with different lactic acid bacteria (LAB) has been used over the years to improve silage fermentation or aerobic stability by delaying the development of yeasts and spoilage molds (Muck et al., 2018). Furthermore, it has been documented that LAB can degraded or immobilize aflatoxins during ensiling by binding to their surface (el-Nezami et al., 1998; Oluwafemi et al., 2010; Ma et al., 2017), thereby contributing to improved safety of feed and food. Ogunade et al. (2018) reported that only a few studies have used additives to reduce forage mycotoxin contamination. In one of these studies (Queiroz et al., 2012), the inoculation of corn plants infested with southern rust with a mixture of Pediococcus pentosaceus and Lactobacillus buchneri at ensiling increased aerobic stability and prevented production of aflatoxins. Some other studies reported that limiting aerobic spoilage by inoculating corn silage with L. buchneri can reduce aflatoxin production (Iglesias et al., 2005; Cavallarin et al., 2011). More recently, Ma et al. (2017) reported that, regardless of LAB inoculation, certain silage bacteria can reduce the concentration of $\mathrm{AFB}_{1}$ that was spiked in corn silage to a safe level within $3 \mathrm{~d}$ of ensiling.

Thus, owing to the lack of clear information in literature, the aims of our study were (1) to evaluate whether the presence of $A$. flavus and aflatoxin production in corn silage originates from the field environment or growth of $A$. flavus takes place and additional aflatoxins are produced during storage or air exposure after silo opening; (2) to evaluate the effect of different LAB inocula used to improve the aerobic stability of corn silage on reducing $A$. flavus growth and aflatoxin production during fermentation and air exposure; and (3) to characterize the toxigenic potential of A. flavus strains isolated from corn silages. 


\section{MATERIALS AND METHODS}

\section{Crop and Ensiling}

The trial was carried out on a commercial farm located in Rocca de ${ }^{\prime}$ Baldi in the western Po plain of northwest Italy $\left(44^{\circ} 27^{\prime} 18^{\prime \prime} \mathrm{N}, 7^{\circ} 43^{\prime} 19^{\prime \prime} \mathrm{E}, 408 \mathrm{~m}\right.$ above sea level). Corn hybrid (P1517W, Pioneer Hi-Bred Italia Srl, Gadesco Pieve Delmona, Cremona, Italy) was sown in April 2015 at an intended planting density of 75,000 seeds/ha. The whole corn crop was harvested at around the $50 \%$ milk line stage and with a DM content of around $34 \%$. Fresh forage was chopped using a precision forage harvester (Claas Jaguar 950, equipped with an 8-row Orbis head, Claas, Harsewinkel, Germany) to a theoretical cutting length of $12 \mathrm{~mm}$. The field was divided in 4 plots, which were subsequently harvested separately, and the crop was chopped to obtain 4 replicates. The fresh herbage of each plot was divided into four $70-\mathrm{kg}$ piles. The piles were either not treated $(\mathbf{C})$ or treated with different LAB strains and their combinations. The LAB strains were L. buchneri (LB) NCIMB 40788 [Lallemand Animal Nutrition, BP 59, Cedex, France; theoretical rate of $300,000 \mathrm{cfu} / \mathrm{g}$ of fresh matter $(\mathbf{F M})]$, Lactobacillus hilgardii $(\mathbf{L H})$ CNCM I-4785 (Lallemand Animal Nutrition; theoretical rate of $300,000 \mathrm{cfu} / \mathrm{g}$ of FM), and their combination $(\mathbf{L B}+\mathbf{L H}$; theoretical rate of $150,000 \mathrm{cfu} / \mathrm{g}$ of $\mathrm{FM}$ of each strain). The microbial inoculants were diluted in sterilized water and applied using a hand sprayer at a rate of $4 \mathrm{~mL} / \mathrm{kg}$ of forage by spraying uniformly onto the forage, which was constantly hand mixed. The same amount of water was added to the $\mathrm{C}$ treatment. To add the targeted amount of LAB, the inocula were plated on de Man, Rogosa, Sharpe agar (Merck, Whitehouse Station, NY), with the addition of natamycin (0.25 $\mathrm{g} / \mathrm{L})$ and, on the basis of the measured concentration of LAB, an appropriate amount was used to achieve the desired application rate.

The fresh forage was sampled before ensiling after the inoculum had been applied. The untreated and treated forage was then ensiled (11 to $13 \mathrm{~kg}$ of wet forage) in 20-L plastic silos equipped with a lid that only enabled the release of gas. The forage was packed by hand, and the final packing densities, on a wet basis, were $627 \pm$ $26 \mathrm{~kg}$ of $\mathrm{FM} / \mathrm{m}^{3}$. All the laboratory silos were filled within $3 \mathrm{~h}$. The silos were weighed, conserved at ambient temperature $\left(20 \pm 1^{\circ} \mathrm{C}\right)$, and opened after $250 \mathrm{~d}$. At opening, each silo was weighed and the content was mixed thoroughly and subsampled to determine the DM content, the chemical composition, the fermentation profile, and the microbial counts. After sampling, the silages were subjected to an aerobic stability test, which involved monitoring the temperature increases due to the microbial activity in the samples exposed to air. About $3 \mathrm{~kg}$ from each silo were allowed to aerobically deteriorate at room temperature $\left(20 \pm 1^{\circ} \mathrm{C}\right)$ in $17-\mathrm{L}$ polystyrene boxes $(290 \mathrm{~mm}$ diameter and $260 \mathrm{~mm}$ height). A single layer of aluminum foil was placed over each box to prevent drying and dust contamination, but also to allow the air to penetrate. The room and silage temperatures were measured hourly by means of a data logger. Aerobic stability was defined as the number of hours the silage remained stable before its temperature increased by $2^{\circ} \mathrm{C}$ above room temperature. From silo opening to $14 \mathrm{~d}$ of air exposure of silages, peak temperature, hours to reach peak temperature, interval to reach $35^{\circ} \mathrm{C}$, and time with temperature greater the $35^{\circ} \mathrm{C}$ were also calculated to better describe the optimum temperature for growth of A. flavus in absence of inhibitory conditions. The silage was sampled after 7 and $14 \mathrm{~d}$ of aerobic exposure to quantify the chemical, fermentative, and microbial changes in the silage during exposure to air, as reported by Tabacco et al. (2011). Other samplings were conducted on d 21 and 28 on the silages that did not show any increase in temperature at $14 \mathrm{~d}$ of air exposure. The DM losses due to fermentation were calculated as the difference between the weight of the forage placed in each plastic silo at ensiling and the weight of the silage at the end of conservation, corrected for the DM content of the forage and its respective silage. The DM losses were calculated after 7 and $14 \mathrm{~d}$ of exposure to air using the ash content, as reported by Borreani et al. (2018). Small increases in the ash content of deteriorated silage represented large percentage unit increases in DM loss, as can be seen when the equation for calculating DM losses according to the ash content is used: DM loss (\%) $=[1-($ ash silage at opening/ash silage after 7 or $14 \mathrm{~d}$ of air exposure $)] \times 100$.

\section{Sample Preparation and Analyses}

The pre-ensiled material and the silage were split into 5 subsamples at both the opening of the silos and before the exposure to air periods (at 7 and $14 \mathrm{~d}$ for all silages and at 21 and $28 \mathrm{~d}$, when needed). One subsample was analyzed immediately for DM content by oven drying at $80^{\circ} \mathrm{C}$ for $24 \mathrm{~h}$. Dry matter was corrected according to Porter and Murray (2001) to consider the volatile compound losses that can take place at $80^{\circ} \mathrm{C}$. The second subsample was oven-dried at $65^{\circ} \mathrm{C}$ to a constant weight and air equilibrated, weighed, and ground in a Cyclotec mill (Tecator, Herndon, VA) to pass a 1-mm screen. The dried samples were analyzed for the total nitrogen according to the Dumas method (method number 992.23; AOAC International, 2005) using a Nitrogen analyzer Primacs SN (Skalar, Breda, the Neth- 
erlands), for $\mathrm{CP}$ (total $\mathrm{N} \times 6.25$ ), for ash by ignition (method number 942.05; AOAC International, 2005), and for water-soluble carbohydrates by the phenol sulphuric acid method according to DuBois et al. (1956). Neutral detergent fiber was analyzed using a Raw Fiber Extractor (FIWE, VELP Scientifica, Usmate Velate, Italy) with the addition of heat-stable amylase (A3306, Sigma Chemical Co., St. Louis, MO) and expressed on a DM basis, including residual ash, as described by Van Soest et al. (1991). Acid detergent fiber was analyzed and expressed on a DM basis, including residual ash (Robertson and Van Soest, 1981).

A third fresh subsample was used to determinate the water activity $\left(\mathbf{a}_{\mathbf{w}}\right), \mathrm{pH}, \mathrm{NO}_{3}, \mathrm{NH}_{3}-\mathrm{N}$ contents, and the buffering capacity. The $\mathrm{a}_{\mathrm{w}}$ was measured at $25^{\circ} \mathrm{C}$ on a fresh sample using an AquaLab Series 3TE (Decagon Devices Inc., Pullman, WA), which adopts the chilledmirror dew point technique. The fresh forage was extracted for $\mathrm{pH}, \mathrm{NO}_{3}$, and $\mathrm{NH}_{3}-\mathrm{N}$ determination using a Stomacher blender (Seward Ltd., Worthing, UK) for 4 min in distilled water at a 9:1 water-to-sample material (fresh weight) ratio. The total nitrate concentration was determined in the water extract through semiquantitative analysis, using Merckoquant test strips (Merck, Darmstadt, Germany; detection limit $100 \mathrm{mg}$ of $\mathrm{NO}_{3} /$ $\mathrm{kg}$ of $\mathrm{DM}$ ). The ammonia nitrogen content and $\mathrm{pH}$ were determined using specific electrodes. The buffering capacity was determined in the water extract, as described by Playne and McDonald (1966).

A fourth subsample was extracted, using a Stomacher blender, for $4 \mathrm{~min}$ in $0.05 \mathrm{~mol} / \mathrm{L}$ of $\mathrm{H}_{2} \mathrm{SO}_{4}$ at a $5: 1$ acidto-sample material (fresh weight) ratio. An aliquot of $40 \mathrm{~mL}$ of silage acid extract was filtered with a $0.20-\mu \mathrm{m}$ syringe filter and used for quantification of the fermentation products. The lactic and monocarboxylic acids (acetic, propionic and butyric acids) were determined, by means of HPLC in the acid extract (Canale et al., 1984). Ethanol and 1,2-propanediol were determined by means of HPLC, coupled to a refractive index detector, on a Aminex HPX-87H column (Bio-Rad Laboratories, Richmond, CA). The fifth subsample was used for the microbial analyses.

\section{Microbial Analysis, Fungal Isolation, Macromorphology, and Sclerotia Production}

To conduct the microbial counts, $30 \mathrm{~g}$ of sample was transferred into a sterile homogenization bag, suspended 1:10 wt/vol in a peptone salt solution $(1 \mathrm{~g}$ of bacteriological peptone and $9 \mathrm{~g}$ of sodium chloride per liter), and homogenized for $4 \mathrm{~min}$ in a laboratory Stomacher blender (Seward Ltd.). Serial dilutions were prepared and the mold and yeast numbers were determined using the pour plate technique with $40.0 \mathrm{~g} / \mathrm{L}$ of yeast extract glucose chloramphenicol agar (YGC agar, Difco, West Molesey, Surrey, UK) after incubation at $25^{\circ} \mathrm{C}$ for 3 and $5 \mathrm{~d}$ for yeast and mold, respectively. The yeast and mold colony-forming units were enumerated separately, according to their macromorphological features, on plates that yielded 1 to $100 \mathrm{cfu}$. The LAB were determined on de Man, Rogosa, Sharpe agar with added natamycin $(0.25 \mathrm{~g} / \mathrm{L})$ by incubating petri plates at $30^{\circ} \mathrm{C}$ for $3 \mathrm{~d}$ under anaerobic conditions, according to Spoelstra et al. (1988). As LAB are facultative anaerobe bacteria, anaerobic incubation was chosen to improve the selectivity of the medium against Bacillus spp.

A subsample of 5 to 10 colonies per sample, with macromorphological features of $A$. section Flavi, was selected for characterization (Table 1). The strains were maintained as a monoconidial culture on $30 \%$ glycerol and stored at $-80^{\circ} \mathrm{C}$. A macro-morphological analysis of each isolate was performed on yeast extract sucrose agar (YES), malt extract autolysate agar (MEA), and czapek yeast autolysate agar (CYA) and observed after $7 \mathrm{~d}$ of incubation at $25^{\circ} \mathrm{C}$ in the dark, according to Samson et al. (2004).

The strains were inoculated on CYA agar and incubated for $14 \mathrm{~d}$ at $30^{\circ} \mathrm{C}$ in the dark to evaluate the sclerotia production (Horn et al., 1996; Horn and Dorner, 1998). The sclerotial size was evaluated by measuring a reticule with a Nikon Eclipse 55i Microscope (Nikon Inc., Garden City, NY) connected to a Samsung color monitor (Samsung Corporation, Seoul, Korea) using $10 \times$ magnification. The strains were identified as small strains $(\mathbf{S})$, with a sclerotial size $<400 \mu \mathrm{m}$ in diameter, or large strains $(\mathbf{L})$, with sclerotia $>400 \mu \mathrm{m}$ in diameter (Horn, 2003).

\section{Molecular Identification}

The isolates were grown on potato dextrose broth $(27$ $\mathrm{g}$, Merck, Germany; in $1 \mathrm{~L}$ of $\mathrm{H}_{2} \mathrm{O}$ ) and incubated at $28^{\circ} \mathrm{C}$ in the dark. We extracted DNA from the mycelium using an Omega E.Z.N.A. Fungal DNA Mini Kit (Omega Bio-tek Inc., Norcross, GA) according to the manufacturer's instructions (http://omegabiotek.com/ store/wp-content/uploads/2013/09/D3390-Fungal -DNA-Mini-Kit-Combo-May-2013-Online-1.pdf). Partial amplification of the calmodulin gene was obtained using the cmd5 and cmd6 primer pair (Hong et al., 2006). We carried PCR out in a total volume of $25 \mu \mathrm{L}$ containing $2.5 \mu \mathrm{L}$ of buffer $10 \times, 0.5 \mu \mathrm{L}$ of $\mathrm{MgCl}_{2}, 0.75$ $\mu \mathrm{L}$ of deoxynucleotide triphosphates $(10 \mathrm{mM}), 1 \mu \mathrm{L}$ of each primer $(10 \mathrm{mM}), 0.2 \mu \mathrm{L}$ of Taq DNA polymerase (Qiagen, Hilden, Germany), and $20 \mathrm{ng}$ of template DNA. A thermal cycling program was performed according to Samson et al. (2014). Amplification was 


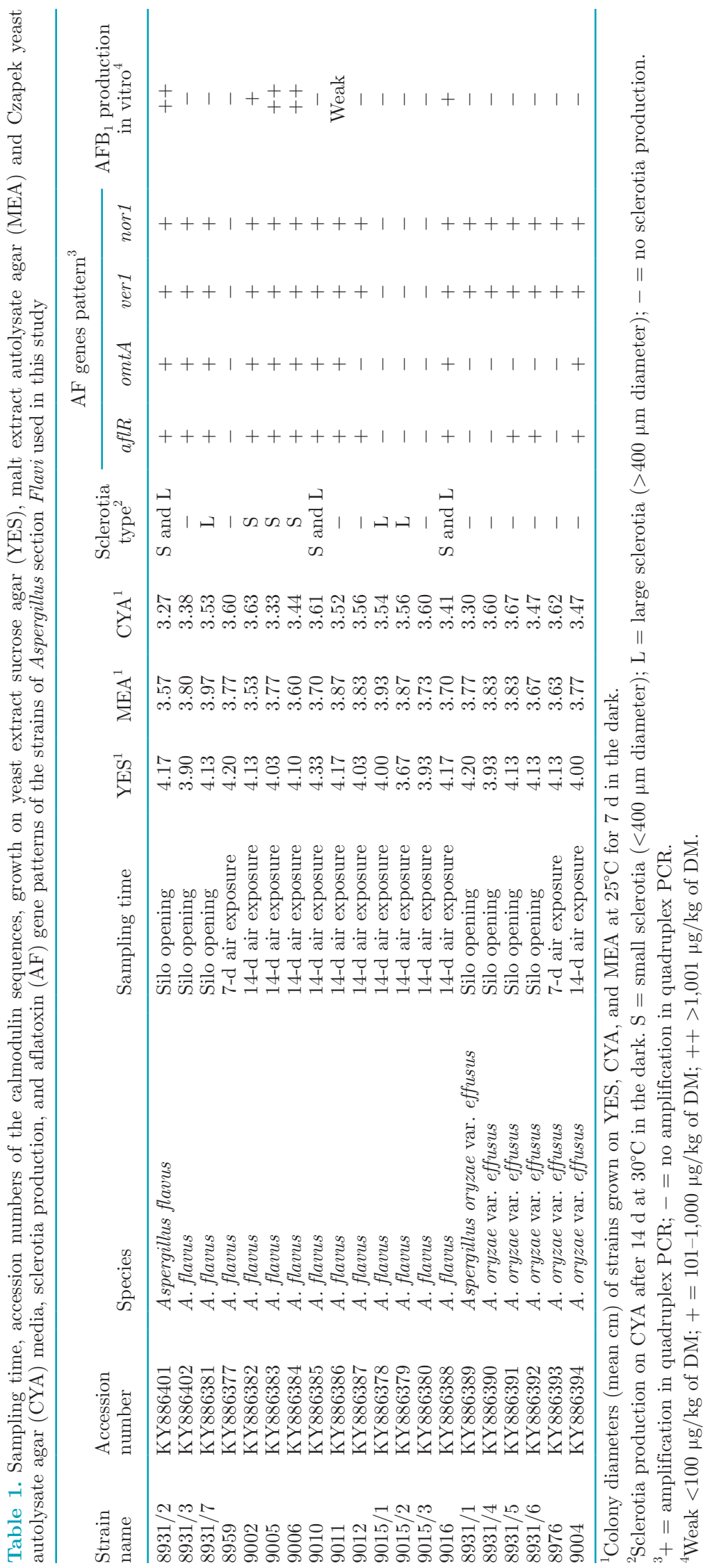


verified by means of electrophoresis on $1 \%$ agarose Tris-acetate EDTA gel, and gel images were acquired using a Gel Doc 1000 System (Bio-Rad Laboratories, Hercules, CA). The PCR products were purified using a QIAquick PCR purification Kit (Qiagen) and sent to Macrogen Inc. (Amsterdam, the Netherlands) for sequencing in both directions. The consensus sequences were obtained using the DNA Baser program (Heracle Biosoft S.R.L., Arges, Romania) and compared using the BLAST program, with the sequences deposited in the RefSeq database of the National Centre for Biotechnology Information (NCBI; https://www.ncbi.nlm .nih.gov/) for species identification. All the sequences are deposited in the GenBank database (https://www .ncbi.nlm.nih.gov/genbank/) with the accession numbers listed in Table 1.

\section{Aflatoxin Gene Detection and Aflatoxin Production In Vitro}

The presence of 4 genes, 3 structural genes (nor1, ver 1 , and omtA) and 1 regulatory gene (aflR), involved in the aflatoxin biosynthesis pathway, which have been studied extensively and used as a diagnostic tool for the differentiation of aflatoxin producing and nonproducing fungi, was verified through a quadruplex PCR assay. Quadruplex PCR was performed using the primers listed in Supplemental Table S1 (https://doi.org/10 .3168/jds.2018-15468). A PCR reaction was carried out in a total volume of $50 \mu \mathrm{L}$ containing $5 \mu \mathrm{L}$ of buffer $10 \times, 1 \mu \mathrm{L}$ of $\mathrm{MgCl}_{2}, 2 \mu \mathrm{L}$ of dNTP $(10 \mathrm{mM}), 1 \mu \mathrm{L}$ of each primer $(10 \mathrm{mM}), 0.4 \mu \mathrm{L}$ of Taq DNA polymerase (Qiagen), and $100 \mathrm{ng}$ of template DNA. A thermal cycling program was performed according to Criseo et al. (2008), with some minor modifications. The PCR products were separated by gel electrophoresis using a Tris-borate EDTA buffer with $2 \%$ agarose and $5 \mu \mathrm{L}$ of SYBRSafe (Invitrogen, Waltham, MA) at $80 \mathrm{~V} / \mathrm{cm}$ for $4 \mathrm{~h}$. A Get Pilot $1 \mathrm{~kb}$ Plus Ladder (100-10,000 bp, Qiagen) was used as a molecular marker and an aflatoxigenic $A$. parasiticus strain AFCAL11 (from the collection of Agroinnova, University of Turin, Italy) was used as positive control. The gel profiles were visualized under UV transilluminator using the Quantity One program (BioRad Labs, Segrate, Italy). The experiment was repeated in triplicate.

The production of aflatoxin was tested for each isolate using a YES medium according to Visagie et al. (2014), with $20 \mathrm{~g} / \mathrm{L}$ of yeast extract, $150 \mathrm{~g} / \mathrm{L}$ of sucrose, $0.5 \mathrm{~g} / \mathrm{L}$ of $\mathrm{MgSO}_{4}$ (Merck, Germany), and 1 $\mathrm{mL}$ of trace elements $\left(1 \mathrm{~g}\right.$ of $\mathrm{ZnSO}_{4} \cdot 7 \mathrm{H}_{2} \mathrm{O}$ and $0.5 \mathrm{~g}$ of $\mathrm{CuSO}_{4} \cdot 5 \mathrm{H}_{2} \mathrm{O}$ in $100 \mathrm{~mL}$ of distilled water). Strains were inoculated with 3 mycelia plugs from a 7 -d-old culture (4 mm diameter) on $50 \mathrm{~mL}$ of medium and incubated in the dark at $35^{\circ} \mathrm{C}$. After $7 \mathrm{~d}$, the cultures were filtered and extracted to establish the aflatoxin production. The samples were extracted and analyzed according to Prencipe et al. (2018).

\section{Aflatoxin Analysis}

The aflatoxins were extracted according to the method reported by Cavallarin et al. (2011). Sample extracts were stored at $-20^{\circ} \mathrm{C}$ until HPLC analysis. The HPLC apparatus consisted of a Dionex P680 pump (Dionex, Sunnyvale, CA) equipped with a Rheodyne Model 7725i injection valve (Rheodyne, Rohnert Park, CA), a Dionex RF-2000 fluorimetric detector (excitation wavelength $=365 \mathrm{~nm}$, emission wavelength $=$ $435 \mathrm{~nm}$ for $\mathrm{AFB}_{1}, \mathrm{AFB}_{2}, \mathrm{AFG}_{1}$, and $\mathrm{AFG}_{2}$ ), a Dionex TCC-100 thermostatted column compartment, and a Chromeleon6 data handling system (Dionex). The analytical column was a ProdigyODS $2(150 \times 4.6 \mathrm{~mm}$, 5- $\mu \mathrm{m}$ particles; Phenomenex, Torrance, CA), which was preceded by a SecurityGuard (Phenomenex) guard column.

\section{Statistical Analysis}

The microbial counts were $\log _{10}$ transformed and presented on a wet weight basis. The values below the detection limit for yeasts and molds (detection levels = $10 \mathrm{cfu} / \mathrm{g}$ of silage) were assigned a value corresponding to half of the detection limit to calculate the average value.

The data were analyzed for their statistical significance, via ANOVA, with their significance reported at a 0.05 probability level using the General Linear Model of SPSS (v 24.0, IBM Corp., Armonk, NY). Data were analyzed using the presence or absence of L. buchneri $(\mathrm{LB}+$ or $\mathrm{LB}-)$ and L. hilgardii $(\mathrm{LH}+$ or $\mathrm{LH}-)$ as fixed factors with 4 replications. The used statistical model was $Y_{i j k}=\mu+\alpha_{i}+\beta_{j}+\alpha \beta_{i j}+\varepsilon_{i j k}$, where $Y_{i j k}=$ observation, $\mu=$ overall mean, $\alpha_{\mathrm{i}}=\mathrm{LB}$ effect $(\mathrm{i}=$ presence or absence of LB), $\beta_{\mathrm{j}}=\mathrm{LH}$ effect $(\mathrm{j}=$ presence or absence of LH), $\alpha \beta_{\mathrm{ij}}=\mathrm{LB} \times \mathrm{LH}$ effect, and $\varepsilon_{\mathrm{ijk}}=$ error. The measured AF were pooled together for silo opening, $7 \mathrm{~d}$ of air exposure, and $14 \mathrm{~d}$ of air exposure, and were corrected for the DM losses. An unpaired $t$-test was used to compare the mean values of the measured $\mathrm{AF}$ and DM loss-corrected values.

\section{RESULTS}

\section{Fermentative, Chemical, and Microbial Parameters}

The chemical and microbial parameters and the AF contamination of the corn forage before ensiling 
are summarized in Table 2 . The chemical values were typical of corn harvested at the $50 \%$ milk line stage. The DM content was $34 \%$ and the NDF, starch, and CP were $42.5,32.3$, and $7.8 \%$ of DM, respectively. The yeast and mold counts were 6.46 and $5.26 \log _{10} \mathrm{cfu} / \mathrm{g}$, respectively. At ensiling, the A. flavus count was below the detection limit and the $\mathrm{AF}$ were present with mean values of $0.055,1.050,0.095$, and $0.044 \mu \mathrm{g} / \mathrm{kg}$ of $\mathrm{DM}$ for $\mathrm{AFB}_{1}, \mathrm{AFB}_{2}, \mathrm{AFG}_{1}$, and $\mathrm{AFG}_{2}$, respectively. Table 3 shows the fermentative parameters after $250 \mathrm{~d}$ of conservation at silo opening and after 7 and $14 \mathrm{~d}$ of air exposure. All the silages were well fermented, with the main acids found at silo opening being lactic and acetic acid; butyric acid was under the detection limit (0.01 $\mathrm{g} / \mathrm{kg}$ of DM). A slight amount of propionic acid was found in the $\mathrm{LB}+\mathrm{LH}$ silages. The presence of $\mathrm{LB}$ and $\mathrm{LH}$ affected the $\mathrm{pH}$, with higher values in the inoculated silages than in the control ones. The LB and LH inocula affected the lactic-to-acetic ratio greatly, and this resulted in values higher than 4 in the $\mathrm{C}$ silages and values that ranged from 1 and 2 in the treated silages. The $\mathrm{LB}+\mathrm{LH}$ silages presented about the half of lactic acid and 2.5 fold the acetic acid compared to C silage. The 1,2-propanediol was present in all the treated silages and ranged from 7.1 to $12.9 \mathrm{~g} / \mathrm{kg}$ of $\mathrm{DM}$, whereas it was not detected in the $\mathrm{C}$ silages. After $7 \mathrm{~d}$ of air exposure, the lactic acid content decreased and $\mathrm{pH}$ increased in all the silages, except for $\mathrm{LB}+\mathrm{LH}$ treatment. The acetic acid content decreased in $\mathrm{C}$ and LH silages, whereas it remained stable in the presence of LB. Ethanol only remained in $\mathrm{LB}+\mathrm{LH}$ treatment. After $14 \mathrm{~d}$ of air exposure, no fermentative products were found in $\mathrm{C}, \mathrm{LB}$, or LH silages, whereas $23.4 \mathrm{~g} / \mathrm{kg}$ of DM of lactic acid and $17.9 \mathrm{~g} / \mathrm{kg}$ of DM of acetic acid were found in the $\mathrm{LB}+\mathrm{LH}$ silages.

The aerobic stability, the temperature indices (as observed from silo opening to $14 \mathrm{~d}$ of air exposure), DM losses, microbial count, and AF concentrations after $250 \mathrm{~d}$ of conservation at silo opening and after 7 and $14 \mathrm{~d}$ of air exposure are reported in Tables 4 and 5. At opening, C silages showed lower DM losses and LAB count than treated silages. The yeast count was under the detection limit in the treatments containing the LB strain. The aerobic stability was affected by the treatments, with the highest value $(365 \mathrm{~h})$ in LB+LH silages. At opening, the mold count was below the detection limit or around $1.00 \log _{10} \mathrm{cfu} / \mathrm{g}$ in all the silages, and the average $A$. flavus count was under the detection limit in 15 out of 16 silage samples. Only 1 LH sample showed the presence of A. flavus, at a level of $1.24 \log _{10} \mathrm{cfu} / \mathrm{g}$. The addition of $\mathrm{LB}$ and $\mathrm{LH}$ did not affect the $\mathrm{AFB}_{1}, \mathrm{AFB}_{2}$, or $\mathrm{AFG}_{2}$ contents, whereas $\mathrm{AFG}_{1}$ was lower in the treatments containing the LH strains. After $7 \mathrm{~d}$ of air exposure, the yeast count increased in all the silages, with the highest value observed in $\mathrm{C}$ silage. The addition of $\mathrm{LB}$ and $\mathrm{LH}$ affected the mold count, with higher values in $\mathrm{C}$ than in the treated silages. Aflatoxin was not influenced by the treatments during air exposure, except for $\mathrm{AFG}_{1}$ after $7 \mathrm{~d}$ in $\mathrm{C}$ silage. In air-exposed silages after $14 \mathrm{~d}$, the $A$. flavus count increased in all the treatments and reached $3.32 \log _{10} \mathrm{cfu} / \mathrm{g}$ in LB silages. Aflatoxin $\mathrm{G}_{1}$ was not detected after $14 \mathrm{~d}$ of air exposure in any treatment, and the other AF did not show any significant difference between treatments. After $14 \mathrm{~d}$ of air exposure, 2 out of $4 \mathrm{LB}+\mathrm{LH}$ samples were still aerobically stable, with the A. flavus count below the detection limit; these samples were left to deteriorate and were sampled after 21 and $28 \mathrm{~d}$. The average $A$. flavus count in these samples was $1.33 \log _{10} \mathrm{cfu} / \mathrm{g}$ and $2.74 \log _{10} \mathrm{cfu} / \mathrm{g}$ after 21 and $28 \mathrm{~d}$, respectively.

During air exposure, when the cumulated hourly difference between silage and ambient temperatures reached $1,000^{\circ} \mathrm{C} \cdot \mathrm{h}$, the yeast had completely depleted the fermentative products, regardless of the treatment and $\mathrm{LAB}$ inoculum, causing a rise in silage $\mathrm{pH}$ greater than 4 (with most of the values ranging from 5.5 to 7 ) and in the silage temperatures around 30 to $40^{\circ} \mathrm{C}$ (Figure 1). A cumulated $1,000^{\circ} \mathrm{C} \cdot \mathrm{h}$ temperature difference was reached at different times during aerobic exposure, the lowest being for $\mathrm{C}$ silages after $176 \mathrm{~h}$ and the highest for LB+HB silages after $484 \mathrm{~h}$. When all the inhibiting conditions $(\mathrm{pH}$ and the presence of undissociated organic acids) were depleted, the total molds and $A$.

Table 2. Chemical and microbiological characteristics of the herbage before ensiling

\begin{tabular}{lcc}
\hline Parameter $^{1}$ & Value & SD \\
\hline $\mathrm{DM}(\%)$ & 34.0 & 1.94 \\
$\mathrm{pH}$ & 5.80 & 0.32 \\
Buffering capacity $(\mathrm{mEq} / \mathrm{kg}$ of $\mathrm{DM})$ & 56 & 9.31 \\
Water activity & 0.996 & 0.00 \\
Nitrate $(\mathrm{mg} / \mathrm{kg})$ & $<100$ & - \\
$\mathrm{NDF}(\%$ of $\mathrm{DM})$ & 42.5 & 1.94 \\
$\mathrm{ADF}(\%$ of $\mathrm{DM})$ & 22.1 & 1.43 \\
$\mathrm{CP}(\%$ of $\mathrm{DM})$ & 7.84 & 0.20 \\
$\mathrm{Ash}(\%$ of $\mathrm{DM})$ & 5.54 & 0.18 \\
Soluble carbohydrates $(\%$ of $\mathrm{DM})$ & 7.37 & 0.89 \\
Starch $(\%$ of $\mathrm{DM})$ & 32.3 & 1.95 \\
$\mathrm{LAB}\left(\log _{10} \mathrm{cfu} / \mathrm{g}\right)$ & 7.71 & 0.56 \\
Yeasts $\left(\log _{10} \mathrm{cfu} / \mathrm{g}\right)$ & 6.46 & 0.29 \\
Molds $\left(\log _{10} \mathrm{cfu} / \mathrm{g}\right)$ & 5.26 & 0.20 \\
Aspergillus flavus $(\log 10 \mathrm{cfu} / \mathrm{g})$ & $<1.00$ & - \\
Aflatoxin $\mathrm{B}_{1}(\mu \mathrm{g} / \mathrm{kg}$ of DM) & 0.055 & 0.077 \\
Aflatoxin $\mathrm{B}_{2}(\mu \mathrm{g} / \mathrm{kg}$ of DM) & 1.050 & 1.498 \\
Aflatoxin $\mathrm{G}_{1}(\mu \mathrm{g} / \mathrm{kg}$ of $\mathrm{DM})$ & 0.095 & 0.147 \\
Aflatoxin $\mathrm{G}_{2}(\mu \mathrm{g} / \mathrm{kg}$ of $\mathrm{DM})$ & 0.044 & 0.059 \\
\hline
\end{tabular}

${ }^{1}$ Values represent the average of 16 replications and the standard deviation. $\mathrm{LAB}=$ lactic acid bacteria. 


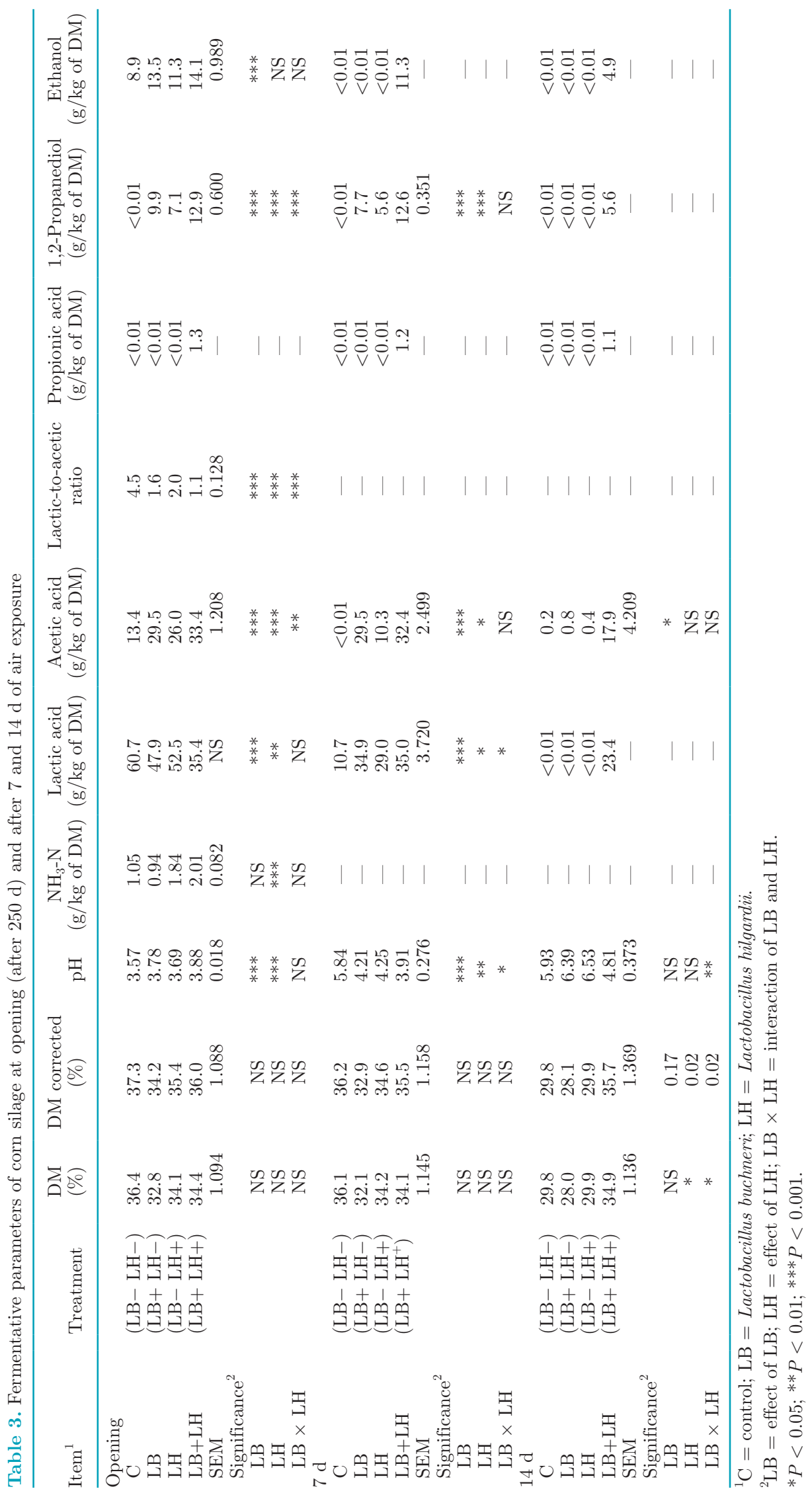


Table 4. Hours of aerobic stability and temperature indices of corn silage during air exposure

\begin{tabular}{|c|c|c|c|c|c|c|}
\hline Opening $^{1}$ & Treatment & $\begin{array}{c}\text { Aerobic } \\
\text { stability } 2^{\circ} \mathrm{C} \\
\text { (h) }\end{array}$ & $\begin{array}{c}\text { Peak } \\
\text { temperature }{ }^{3} \\
\left({ }^{\circ} \mathrm{C}\right)\end{array}$ & $\begin{array}{c}\text { Interval to peak } \\
\text { temperature } \\
\text { (h) }\end{array}$ & $\begin{array}{c}\text { Interval to } \\
35^{\circ} \mathrm{C}^{3} \\
(\mathrm{~h})\end{array}$ & $\begin{array}{c}\text { Interval with } \\
\text { temperature } \\
>35^{\circ} \mathrm{C}^{3}(\mathrm{~h})\end{array}$ \\
\hline $\mathrm{C}$ & $(\mathrm{LB}-\mathrm{LH}-)$ & 102 & 51 & 213 & 117 & 180 \\
\hline LH & $(\mathrm{LB}-\mathrm{LH}+)$ & 124 & 48 & 251 & 139 & 182 \\
\hline $\mathrm{LB}+\mathrm{LH}$ & $(\mathrm{LB}+\mathrm{LH}+)$ & 365 & 35 & 332 & 294 & 37 \\
\hline SEM & & 50.1 & 3.33 & 7.80 & 12.8 & 18.2 \\
\hline $\mathrm{LB} \times \mathrm{LH}$ & & NS & NS & $*$ & $* *$ & * \\
\hline
\end{tabular}

${ }^{1} \mathrm{C}=$ control $; \mathrm{LB}=$ Lactobacillus buchneri $\mathrm{LH}=$ Lactobacillus hilgardii.

${ }^{2} \mathrm{LB}=$ effect of $\mathrm{LB} ; \mathrm{LH}=$ effect of $\mathrm{LH} ; \mathrm{LB} \times \mathrm{LH}=$ interaction of $\mathrm{LB}$ and $\mathrm{LH}$.

${ }^{3}$ As observed from silo opening to $14 \mathrm{~d}$ of air exposure.

${ }^{*} P<0.05 ;{ }^{* *} P<0.01 ;{ }^{* * *} P<0.001$.

flavus quickly started to increase (Figure 2). The DM losses in all the silages increased during exposure to air and reached the highest value in $\mathrm{C}$ silage and the lowest in $\mathrm{LB}+\mathrm{LH}$ silage after $14 \mathrm{~d}$. As the actual concentration of AF in the silage samples should take into account in the amount of DM losses, Figure 3 reports the $\mathrm{AFB}_{1}, \mathrm{AFB}_{2}, \mathrm{AFG}_{1}$, and $\mathrm{AFG}_{2}$ concentrations from ensiling to the end of conservation as well as after 7 and $14 \mathrm{~d}$ of air exposure for both the potential amount of AF derived from the field (corrected for DM losses during conservation and air exposure), hypothesizing no new biosynthesis or degradation, and their actual measured contents. The $\mathrm{AFB}_{1}$ increased during silage conservation and during air exposure, with higher values observed after $14 \mathrm{~d}$ of conservation, whereas $\mathrm{AFB}_{2}$ did not increase significantly during conservation compared with its increase due to DM losses. On the other hand, the $\mathrm{AFG}_{1}$ content decreased during conservation and subsequent exposure to air. Aflatoxin $G_{2}$ was not affected by the ensiling process or aerobic deterioration, even though it apparently increased when the DM losses were not taken into account.

The nutritional analyses after $250 \mathrm{~d}$ of conservation at silo opening and after 7 and $14 \mathrm{~d}$ of air exposure are reported in Table 6. At opening, no differences between treatments were found among the studied nutritional parameters. After $7 \mathrm{~d}$ of air exposure, a slight increase of starch was observed in C, LB, and LH silages, as well as a reduction in NDF. The CP increased after $14 \mathrm{~d}$ of exposure to air. After $1,000^{\circ} \mathrm{C} \cdot \mathrm{h}$, when mold activity was evident, the starch content corrected for DM losses decreased greatly, reaching values below $10 \%$ of DM (Figure 1). After $14 \mathrm{~d}$ of exposure to air, an increase of NDF, ADF, hemicellulose, CP, and ash was observed, and this was more evident in $\mathrm{C}, \mathrm{LB}$, and $\mathrm{LH}$ silages than in $\mathrm{LB}+\mathrm{LH}$ silages.

\section{Strain Identification, Macro-Morphology, and Sclerotia Production}

Representative subsamples of the isolated strains of Aspergillus section Flavi obtained from silage at opening, after $7 \mathrm{~d}$ of air exposure, and after $14 \mathrm{~d}$ of air exposure were used for the analysis. A data set of $532 \mathrm{bp}$ for the partial sequence of the calmodulin gene was obtained for each strain. The majority of isolates $(14 / 20)$ resulted to belong to the $A$. flavus species, whereas other isolates $(6 / 20)$ were identified as $A$. oryzae var. effusus and showed $100 \%$ identity with the RefSeq deposit in GenBank (Table 1). A second subsample of Aspergillus section Flavi, obtained from silage after $21 \mathrm{~d}$ of exposure to air (4 isolates) and after $28 \mathrm{~d}$ of exposure to air (4 isolates) was used for the analysis (data not shown). All 4 isolates from the $\mathrm{LB}+\mathrm{LH}$ samples at $21 \mathrm{~d}$ of exposure to air belonged to the A. oryzae var. effusus species (9026/1, 9026/2, 9026/3, and 9026/4). After 28 $\mathrm{d}$ of exposure to air, 2 out of 4 isolates were identified as A. flavus (9031/1 and $9031 / 2$ ) and 2 as A. oryzae var. effusus (9031/3 and 9031/4).

The typical morphology of Aspergillus section Flavi was observed with yellow to green conidia, as well as a mean diameter of 40.7, 37.6, and $35.0 \mathrm{~mm}$ for YES, MEA, and CYA, respectively. The A. oryzae var. effusus strains showed poor sporulation, with a white surface and irregular margins, as well as a mean diameter of 40.9, 37.5, and $35.2 \mathrm{~mm}$ for YES, MEA, and CYA, respectively (Table 1 ).

Nine out of 14 A. flavus produced sclerotia, whereas none of the strains of $A$. oryzae var. effusus were able to produce them (Table 1). The 8931/2, 9010, and 9016 strains produced both $\mathrm{S}$ and L sclerotia, the 8931/7, 9015/1, and 9015/2 strains produced L sclerotia, whereas the 9002, 9005, and 9006 strains produced S 


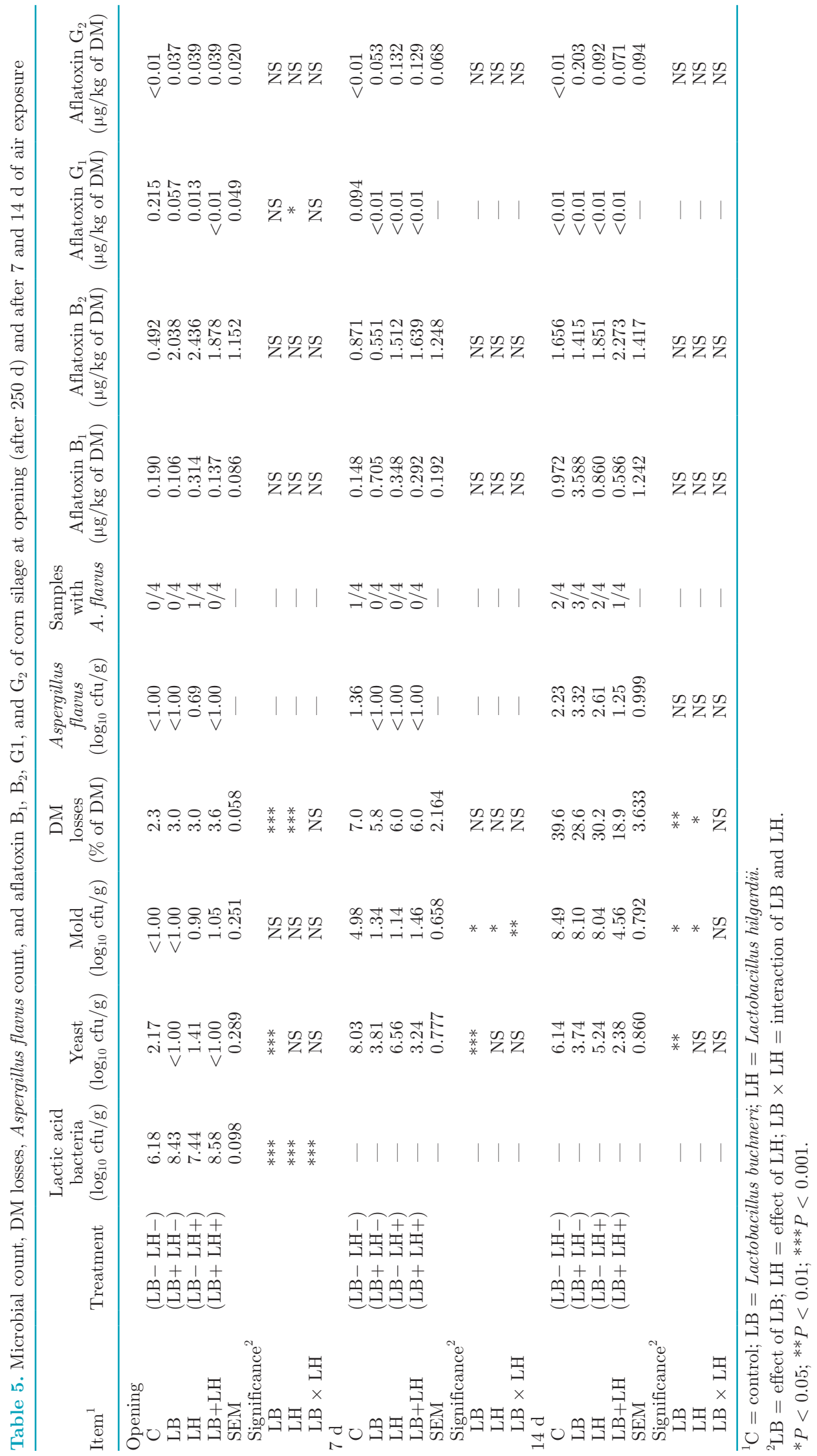


A

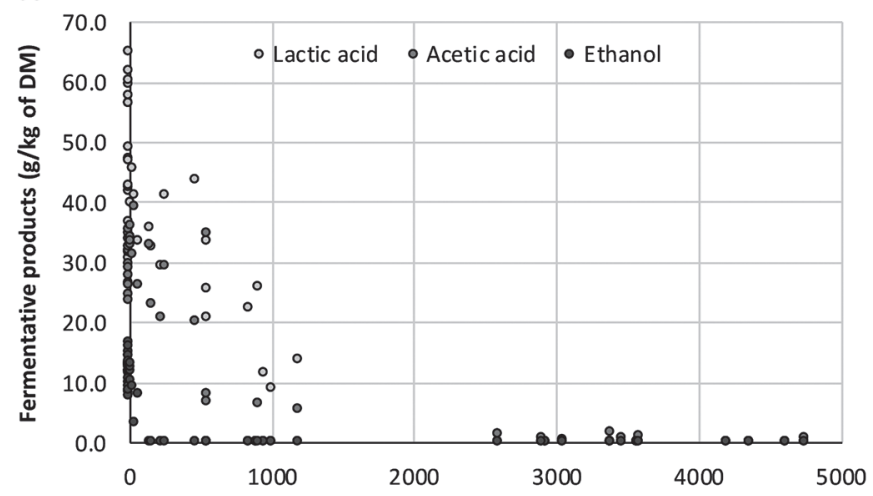

B

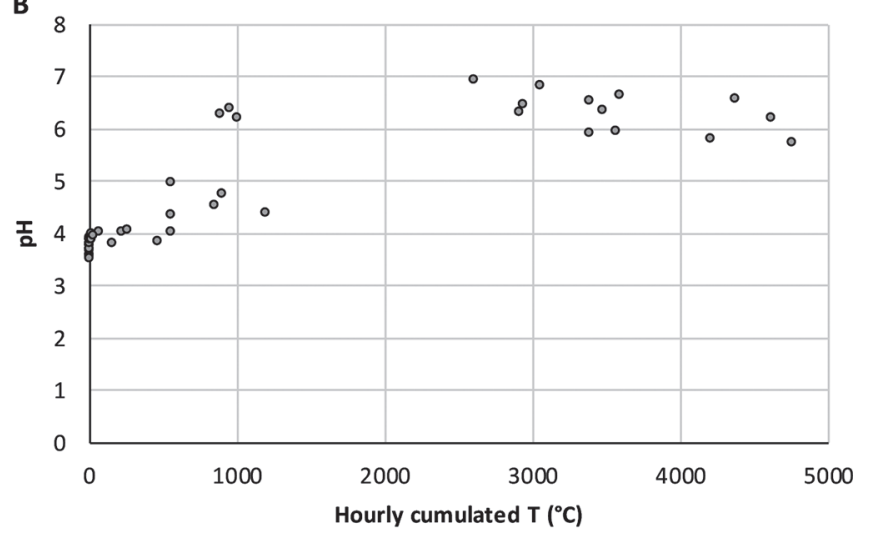

C

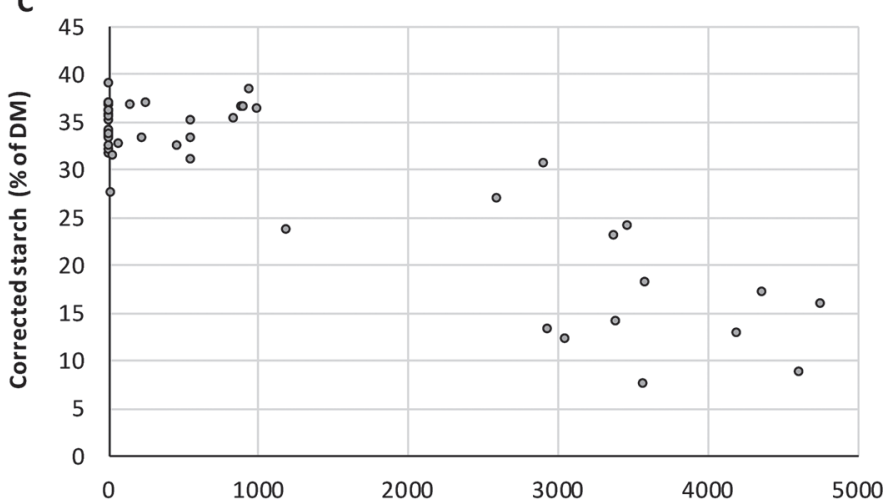

D

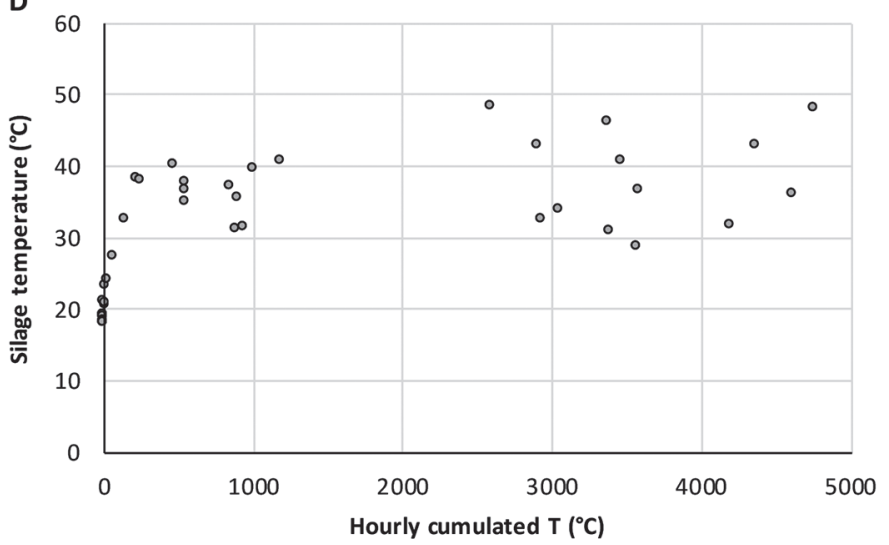

Figure 1. Scatter plot of fermentative products in relation to hourly accumulated temperature $(\mathrm{T})$ rise $\left({ }^{\circ} \mathrm{C} \cdot \mathrm{h}\right)$ above the ambient temperature over air exposure $(\mathrm{A})$; of $\mathrm{pH}$ in relation to the hourly accumulated temperature rise $\left({ }^{\circ} \mathrm{C} \cdot \mathrm{h}\right)$ above the ambient temperature over air exposure (B); starch content corrected for DM losses during air exposure in relation to the hourly accumulated temperature rise $\left({ }^{\circ} \mathrm{C} \cdot \mathrm{h}\right)$ above the ambient temperature over air exposure $(\mathrm{C})$; and silage temperature in relation to the hourly accumulated temperature rise $\left({ }^{\circ} \mathrm{C} \cdot \mathrm{h}\right)$ above the ambient temperature over air exposure (D).

sclerotia. The $8959,8931 / 3,9012$, and $9015 / 3$ strains did not produce any sclerotia.

\section{Aflatoxin Production In Vitro and Aflatoxin Gene Detection}

After $14 \mathrm{~d}$ of incubation at $35^{\circ} \mathrm{C}$ in the dark on YES, 6 out 14 A. flavus were able to produce $\mathrm{AFB}_{1}$, whereas none of the $A$. oryzae var. effusus strains seemed to be able to produce them (Table 1). Quadruplex PCR for gene detection produced the expected size amplicons in the positive control, with around 1,000, 800, 500, and $400 \mathrm{bp}$ for the aflR, omtA, ver1, and nor 1 genes, respectively (Figure 4). All the aflatoxigenic A. flavus strains showed a complete molecular pattern with the 4 analyzed genes. The nonaflatoxigenic A. flavus strains showed different banding pattern results. No DNA amplification was found for the A. flavus 8959, 9015/1, $9015 / 2$, and $9015 / 3$ strains for any of the genes. As far as the A. oryzae var. effusus strains are concerned, quadruplex PCR showed 3 banding patterns: strains 8976, 8931/1 and 8931/4 with 2 bands, corresponding to the ver 1 and nor 1 genes, a second group with 3 bands corresponding to aflR, ver1, and nor 1 amplification (8931/5 and 8931/6 strains), and 1 strain (9004) with the complete pattern.

\section{DISCUSSION}

In light of the potential risk of mycotoxin contamination, we considered it important to obtain information about the type and distribution of AF in corn silage, which is the main source of forage for lactating dairy cows in Europe and North America. Furthermore, a possible effect of different LAB inocula on the growth of spoilage molds has also been evaluated. The longer the anaerobic phase of silage is, the greater the reduction in yeast and mold counts (Borreani et al., 2014); this implicates that silage is not a favorable environment for mold development during conservation if anaerobiosis 


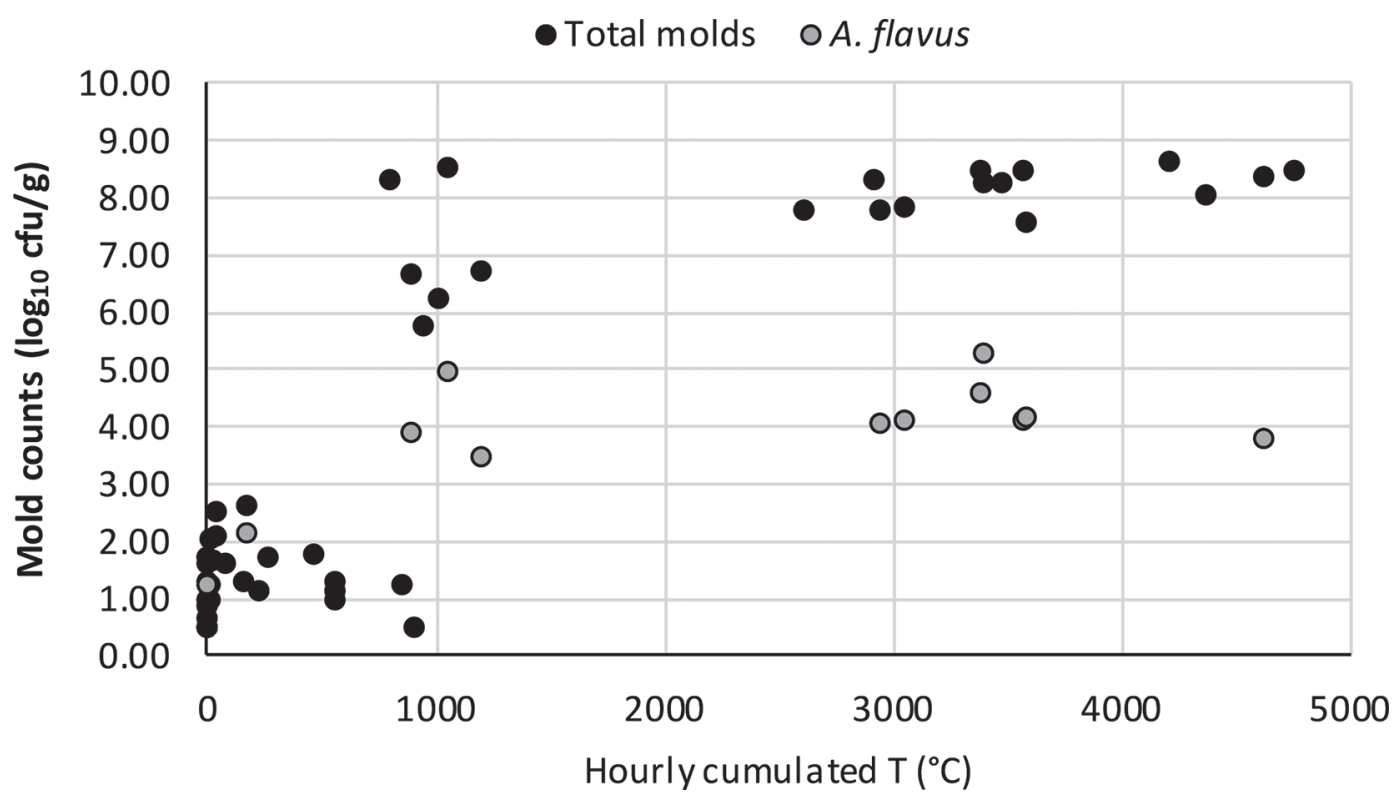

Figure 2. Scatter plot between the total mold and Aspergillus flavus counts and the hourly accumulated temperature rise $\left({ }^{\circ} \mathrm{C} \cdot \mathrm{h}\right)$ above the ambient temperature over air exposure.

is maintained (Borreani et al., 2018). In the present experiment, the presence of $A$. flavus was found to be below the detection limit $\left(<1.00 \log _{10} \mathrm{cfu} / \mathrm{g}\right)$ in the fresh forage before ensiling, in which the mold count was observed to be higher than $5 \log _{10} \mathrm{cfu} / \mathrm{g}$. At silo opening, after a long ensiling period $(250 \mathrm{~d})$, the mold count was around or below $1.00 \log _{10} \mathrm{cfu} / \mathrm{g}$ of silage, whereas $A$. flavus was found in 1 out of 16 silage samples $\left(1.24 \log _{10}\right.$ $\mathrm{cfu} / \mathrm{g}$, which represents around $45 \%$ of the total molds of that sample). This could suggest that A. flavus was already present in the field and that it survived after the anaerobic conservation period, whereas many other mold species did not. This hypothesis is also supported by the presence of AF in the herbage before ensiling, which means that $A$. flavus must have developed on the crop during the growing cycle, albeit at a low level, and synthesized AF.

Over the last decade, the Po plain environment has been characterized by warmer and drier summers than in previous decades, and these conditions could have favored the development of $A$. flavus on the corn crops and AF synthesis. This could explain the increased frequency of $\mathrm{AFB}_{1}$ contamination observed on corn grain and silages in the last few years (Decastelli et al., 2007). The presence of $A$. flavus on corn crops at a low level at our latitudes could be explained by the occurrence of some periods with higher ambient temperatures than $35^{\circ} \mathrm{C}$ in summer, as this is the optimal growth temperature for the fungus and these increased temperatures generally cause it to be the predominant species in tropical and subtropical climates (Cheli et al., 2013). In this regard, González-Pereyra et al. (2008) found A. flavus as the predominant species, followed by Aspergillus fumigatus and Aspergillus niger, in different farm corn silages in the tropical environment of central Argentina. Keller et al. (2013) found A. flavus as the predominant Aspergillus species at both ensiling and at silo opening in Brazil, and El-Shanawany et al. (2005), in a farm survey, found $A$. flavus as the dominant species in corn silage in Egypt. On the other hand, Garon et al. (2006) and Spadaro et al. (2015) did not find A. flavus in corn silage in the temperate climates of France or northern Italy, but instead reported the presence of $A$. parasiticus and A. fumigatus. However, Richard et al. (2007) detected $A$. flavus in farm corn silage in France after 11 mo of conservation. This indicates that the fungus is able to survive during the anaerobic conservation phase of corn silage, albeit at a low level, and could grow when the environmental conditions become more suitable for its growth, such as during the feed-out phase or in peripheral areas of the silage, where temperatures increase as a consequence of a deteriorating microflora activity, which depletes the acidic conditions.

In the present experiment, even though $A$. flavus was below the detection limit in the fresh forage before ensiling and it was present at a low level at silage opening, $\mathrm{AF}$ were found in both the fresh forage and at opening in all the samples, with a predominance of $\mathrm{AFB}_{2}$. The presence of $\mathrm{AF}$ has been found at silo opening in different countries of the world, as reviewed by Alonso 
et al. (2013), with higher concentrations in warmer climates (Carvalho et al., 2016; Ogunade et al., 2018) than in colder ones (Driehuis et al., 2008; Cavallarin et al., 2011).

In our experiment, the inoculation with heterolactic bacteria, which was aimed at improving the aerobic stability of silage during the feed-out phase, and the long ensiling duration $(250 \mathrm{~d})$ influenced the fermentative profile of the silages, with a dominant homolactic fermentation (lactic-to-acetic ratio $>4$ ) in the control silages and a heterolactic fermentation (lactic-to-acetic ratio $<2$ ) in LB- and LH-treated silages, as previously reported by Kleinschmit and Kung (2006). The 1,2-propanediol found in LB silages, as previously reported by Oude Elferink et al. (2001), and in LH silages was in agreement with the results of Assis et al. (2014). The fermentation process, combined with the longer ensiling duration, greatly reduced the yeast and mold count compared with those observed at harvesting. Furthermore, the inocula containing LB showed a reduction in yeast to below the detection limit, as reported by Kleinschmit and Kung (2006). The use of heterolactic inocula causes greater DM losses during fermentation, and greater DM losses could cause a higher concentration of nondegraded components (e.g., ashes). Therefore, to obtain a better understanding of the fate of different $\mathrm{AF}$ in silage, due to the fact that they could be produced both in the field and during ensiling and at the same time could be degraded or bound by LAB microbial activity (Oluwafemi et al., 2010) or bound by other silage bacteria (Ma et al., 2017), it is important to keep in mind that they could concentrate in silage as a consequence of DM losses. Such a scenario is evident in Figure 3, where it appears that the $\mathrm{AFB}_{1}$ increased slightly during the fermentation process and increased significantly after 7 and $14 \mathrm{~d}$ of exposure to air. Aflatoxin $\mathrm{B}_{2}$ and $\mathrm{AFG}_{2}$ were not affected by the anaerobic fermentation phase or by the subsequent exposure to air, and their higher concentration in deteriorated silages could mainly be attributed to the DM losses. On the other hand, $\mathrm{AFG}_{1}$ was partially degraded during the ensiling process and almost completely disappeared after $14 \mathrm{~d}$ of air exposure. Cavallarin et al. (2011) analyzed the presence of AF in both fresh forage and after ensiling in silage stored under different plastic films and, during feed out, they found that AF were absent
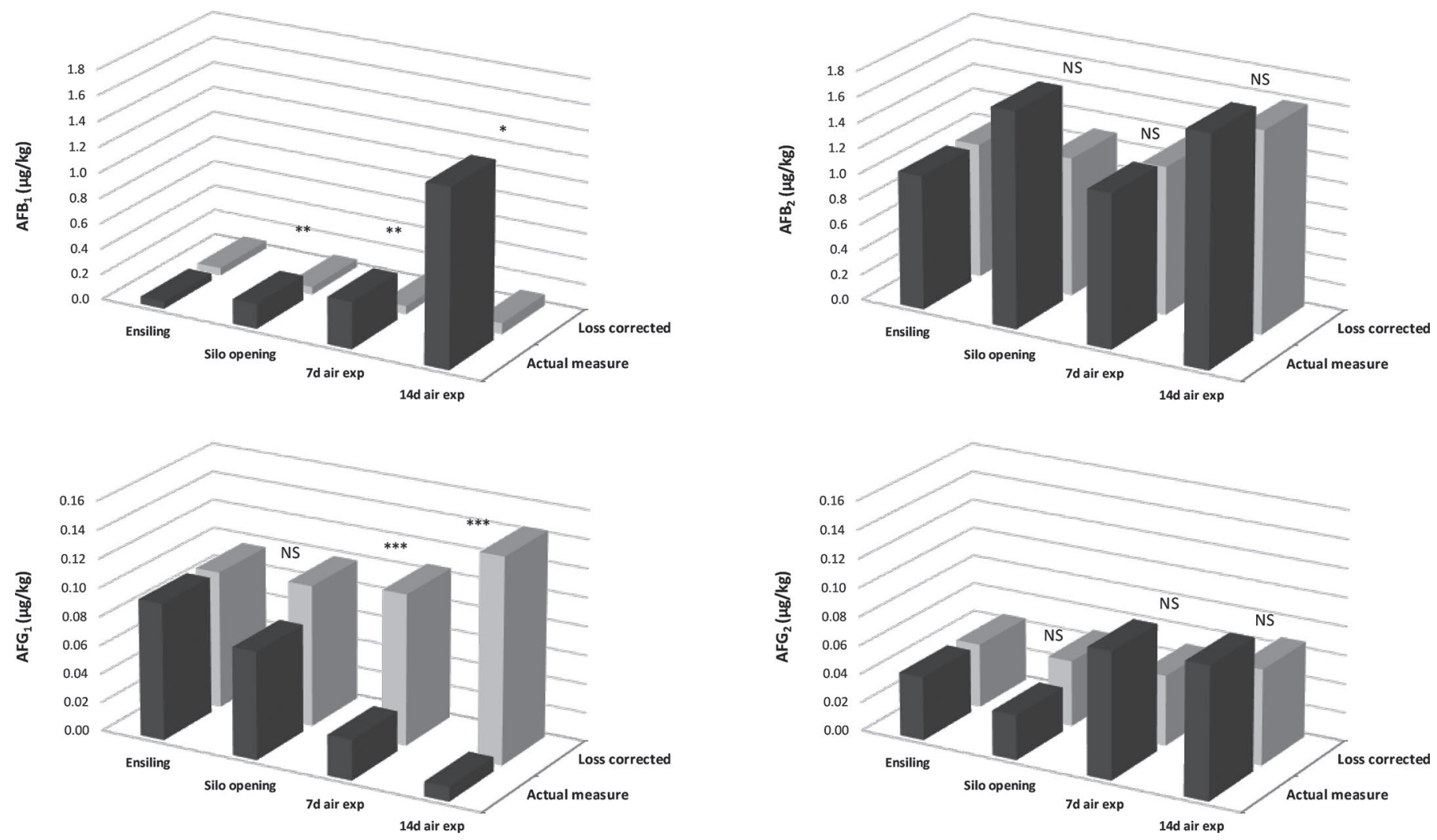

Figure 3. Concentration of aflatoxin $(\mathrm{AF}) \mathrm{B}_{1}, \mathrm{AFB}_{2}, \mathrm{AFG}_{1}$, and $\mathrm{AFG}_{2}$ from ensiling to end of conservation and after 7 and $14 \mathrm{~d}$ of air exposure (exp); data from different treatments are pooled together. In gray is the potential amount of aflatoxins derived from the field corrected for DM losses hypothesizing no new biosynthesis or degradation; in black is the actual measured content. ${ }^{*} P<0.05 ;{ }^{* *} P<0.01 ; * * * P<0.001$. 
Table 6. Nutritional analyses of corn silage at opening (after $250 \mathrm{~d}$ ) and after 7 and $14 \mathrm{~d}$ of air exposure

\begin{tabular}{|c|c|c|c|c|c|c|c|}
\hline Item $^{1}$ & Treatment & $\begin{array}{c}\text { Starch } \\
(\% \text { of DM) }\end{array}$ & $\begin{array}{c}\mathrm{NDF} \\
(\% \text { of DM) }\end{array}$ & $\begin{array}{c}\mathrm{ADF} \\
(\% \text { of } \mathrm{DM})\end{array}$ & $\begin{array}{l}\text { Hemicellulose } \\
\text { (\% of DM) }\end{array}$ & $\begin{array}{c}\mathrm{CP} \\
(\% \text { of } \mathrm{DM})\end{array}$ & $\begin{array}{c}\text { Ash } \\
(\% \text { of DM) }\end{array}$ \\
\hline \multicolumn{8}{|l|}{ Opening } \\
\hline $\mathrm{C}$ & $(\mathrm{LB}-\mathrm{LH}-)$ & 34.6 & 37.0 & 19.4 & 17.6 & 8.5 & 4.66 \\
\hline $\mathrm{LH}$ & $(\mathrm{LB}-\mathrm{LH}+)$ & 33.1 & 39.2 & 20.9 & 18.3 & 8.8 & 5.14 \\
\hline $\mathrm{LB}+\mathrm{LH}$ & $(\mathrm{LB}+\mathrm{LH}+)$ & 35.0 & 38.7 & 20.5 & 18.2 & 8.5 & 5.02 \\
\hline SEM & \multicolumn{6}{|c|}{ Significance ${ }^{2}$} & 0.158 \\
\hline LH & & NS & NS & NS & NS & NS & NS \\
\hline $\mathrm{LB} \times \mathrm{LH}$ & & NS & NS & NS & NS & NS & NS \\
\hline \multicolumn{8}{|l|}{$7 \mathrm{~d}$} \\
\hline $\mathrm{C}$ & $(\mathrm{LB}-\mathrm{LH}-)$ & 39.3 & 35.0 & 18.8 & 16.3 & 7.6 & 4.88 \\
\hline LB & $(\mathrm{LB}+\mathrm{LH}-)$ & 36.5 & 37.3 & 20.0 & 17.3 & 8.1 & 5.31 \\
\hline $\mathrm{LH}$ & $(\mathrm{LB}-\mathrm{LH}+)$ & 36.4 & 38.1 & 20.0 & 18.1 & 8.4 & 5.29 \\
\hline $\mathrm{LB}+\mathrm{LH}$ & $(\mathrm{LB}+\mathrm{LH}+)^{\prime}$ & 35.7 & 38.0 & 20.1 & 17.9 & 8.6 & 5.14 \\
\hline \multicolumn{8}{|l|}{$14 \mathrm{~d}$} \\
\hline $\mathrm{C}$ & $(\mathrm{LB}-\mathrm{LH}-)$ & 18.1 & 56.4 & 35.3 & 21.1 & 17.7 & 7.27 \\
\hline LB & $(\mathrm{LB}+\mathrm{LH}-)$ & 26.8 & 51.5 & 31.0 & 20.5 & 12.8 & 6.91 \\
\hline LH & $(\mathrm{LB}-\mathrm{LH}+)$ & 26.0 & 50.1 & 30.5 & 19.7 & 13.4 & 6.96 \\
\hline $\mathrm{LB}+\mathrm{LH}$ & $(\mathrm{LB}+\mathrm{LH}+)$ & 33.5 & 42.1 & 23.4 & 18.7 & 9.6 & 5.90 \\
\hline SEM & & 2.859 & 2.734 & 1.937 & 0.523 & 0.869 & 0.424 \\
\hline \multicolumn{8}{|l|}{ Significance $^{2}$} \\
\hline LB & & $*$ & $*$ & $* *$ & $* * *$ & NS & NS \\
\hline $\mathrm{LH}$ & & * & ** & ** & $*$ & NS & NS \\
\hline $\mathrm{LB} \times \mathrm{LH}$ & & NS & NS & NS & NS & NS & NS \\
\hline
\end{tabular}

${ }^{1} \mathrm{C}=$ control $; \mathrm{LB}=$ Lactobacillus buchneri $; \mathrm{LH}=$ Lactobacillus hilgardii

${ }^{2} \mathrm{LB}=$ effect of $\mathrm{LB} ; \mathrm{LH}=$ effect of $\mathrm{LH} ; \mathrm{LB} \times \mathrm{LH}=$ interaction of $\mathrm{LB}$ and $\mathrm{LH}$.

${ }^{*} P<0.05 ;{ }^{* *} P<0.01 ;{ }^{* * *} P<0.001$.

in the center of the bunker silos, whereas they were present with values of up to $6 \mu \mathrm{g} / \mathrm{kg}$ of $\mathrm{DM}$ in the top layer of the bunker. In contrast to the results of the present study and those of Cavallarin et al. (2011), Garon et al. (2006) observed, in farm-scale silos, a decrease in the $\mathrm{AFB}_{1}$ content as the ensiling duration increased. This could be attributable to a detoxification effect during fermentation, as reported by Oluwafemi et al. (2010), who observed that some strains of LAB are able to partially degrade $\mathrm{AFB}_{1}$ in corn grain via a biological pathway, with a reduction range from 31 to $46 \%$. Ahlberg et al. (2015), reviewing the ability of different $\mathrm{LAB}$ species and strains to bind $\mathrm{AF}$ in different food matrices, reported binding effects ranging from 0 to $90 \%$, but their review did not report any research results concerning inoculation trials with L. buchneri or L. hilgardii. Ma et al. (2017) reported the capacity of binding $\mathrm{AFB}_{1}$ in vitro by some strains of $\mathrm{LAB}$ when applied at $10^{9} \mathrm{cfu} / \mathrm{mL}$ (Lactobacillus plantarum, L. buchneri, and Pediococcus acidilactici); however, those authors failed to find the same effect on corn silage artificially contaminated with $\mathrm{AFB}_{1}$, although they concluded that some silage bacteria could have reduced the $\mathrm{AFB}_{1}$ to a safe content within $3 \mathrm{~d}$ of ensiling regardless of LAB inoculation. In the present experiment, even though the conservation period was $250 \mathrm{~d}$ long, AF concentrations did not decrease compared with AF present in the fresh forage.

One of the most relevant issues of corn silage around the world is its susceptibility to aerobic deterioration, which negatively influences the silage nutritive value, animal performance, and farm profitability (Borreani et al., 2018). To better understand the role of air on the reduction of the nutritional value and on the increase in DM losses during aerobic deterioration, silages were left to deteriorate in laboratory trials for up to $14 \mathrm{~d}$. This time period was chosen to represent the average age of silages in the peripheral areas of farm bunker silos at risk to exposure to air when a feed-out rate of 0.7 to 1.4 $\mathrm{m} / \mathrm{wk}$ is adopted (Borreani and Tabacco, 2008; Weinberg et al., 2009), which results in a potential aerobic exposure of the silage of 10 to $20 \mathrm{~d}$. In our experiment, the inocula improved aerobic stability compared with the control, and this is in agreement with previous 
studies about the efficiency of L. buchneri (Arriola et al., 2011; Comino et al., 2014) and L. hilgardii (Assis et al., 2014). In agreement with the findings reported by Tabacco et al. (2011), the deteriorated silages of the present study showed an increase in the yeast and mold counts and a reduction of their nutritive value, with a substantial decrease in starch and an increase in the fiber and ash concentrations.

At the beginning of aerobic deterioration, the mold count values were close to those observed at silo opening, whereas the yeasts increased to values higher than $5 \log _{10} \mathrm{cfu} / \mathrm{g}$; the developing yeast depleted the fermentative products (first the ethanol and then the acetic and lactic acid) and caused an increase in the $\mathrm{pH}$ and silage temperature (Figure 1). Irrespective of the treatment, when the hourly cumulated temperature reached $1,000^{\circ} \mathrm{C}$, all the inhibiting conditions for mold growth (undissociated organic acids) were depleted and the mean $\mathrm{pH}$ was $6.19 \pm 0.62$. At the same time, the silage temperature increased to over $35^{\circ} \mathrm{C}$ (with an average value of $38.7 \pm 6.3^{\circ} \mathrm{C}$ ). These lowered inhibiting conditions allowed the growth of both the total molds and $A$. flavus, which reached values higher than 8.00 and 4.00 $\log _{10} \mathrm{cfu} / \mathrm{g}$, respectively. Those conditions were observed in both the control and LAB-treated silages after about $70 \mathrm{~h}$ from the time at which the temperature started to rise above the ambient temperature (data not shown), with LB- and LH-treated silage showing a longer period of aerobic stability. This means that all the silages (both the control and LAB-inoculated ones) are prone to the development of $A$. flavus during exposure to air, and this development takes place when silage stability has already been compromised $(\mathrm{pH}$ and temperature higher than 5 and $35^{\circ} \mathrm{C}$, respectively). Cavallarin et al. (2011) provided evidence of AF accumulation in whole-crop corn silage as a result of aerobic deterioration, which had previously been hypothesized by other authors that had found higher contaminations of AF in peripheral areas of commercial silos, which are known to be the most prone to aerobic deterioration (Rosiles, 1978; Richard et al., 2009). The results of this experiment have also shown that the use of LAB inocula, which are able to shift silage fermentation toward a more heterolactic pathway, could delay the onset of aerobic deterioration after exposure to air of the silage, and, as a consequence, could stave off A. flavus development and AF synthesis. Results are in agreement with data of Queiroz et al. (2012), who found that when corn infested with southern rust was inoculated with a mixture of $P$. pentosaceus and L. buchneri at ensiling, its aerobic stability increased and the production of AF was prevented compared with an untreated control. Our results are also in agreement with Cavallarin et al. (2011), who reported that inoculation with L. buchneri delayed the onset of aerobic deterioration and the synthesis of AF. In the present experiment we also observed, as previously reported by Cavallarin et al. (2011), that, when deterioration have took place, the total AF concentration in L. buchneri-treated silages increased more than in the control or in L. plantaruminoculated silage.

The environment resulting from aerobic deterioration allowed $A$. flavus to grow and $\mathrm{AFB}_{1}$, which was produced ex novo during ensiling and air exposure, to increase. To verify the aflatoxigenic potential of the selected colonies of $A$. flavus, 4 genes involved in the aflatoxin biosynthesis pathway were analyzed through a quadruplex PCR and an in vitro assay was performed. Nine

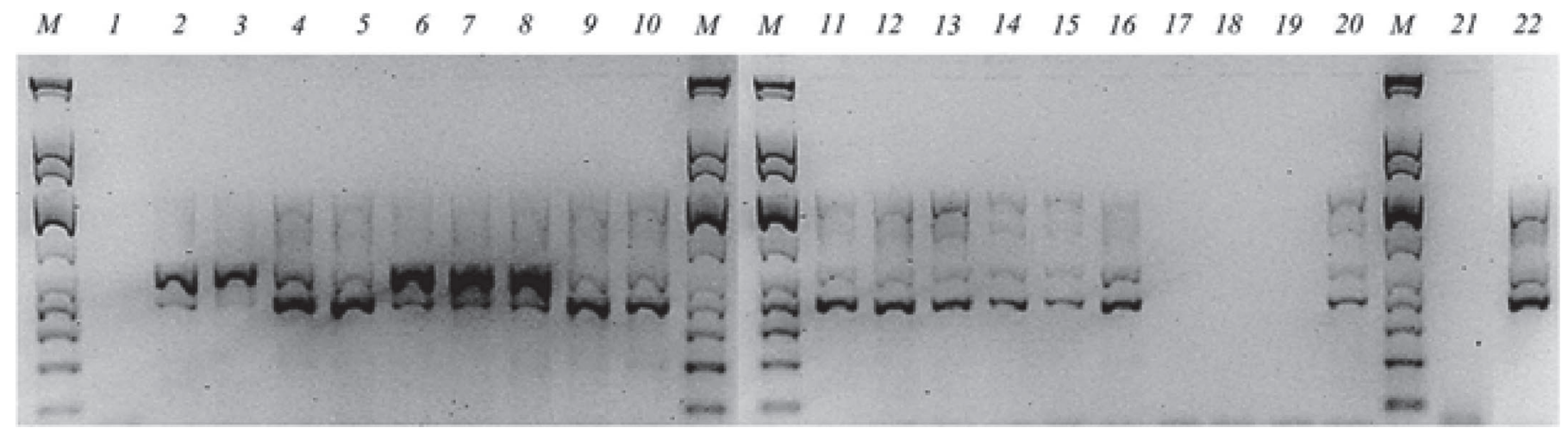

Figure 4. Agarose gel electrophoresis of quadruplex PCR products for strains used in this study. Lane $\mathrm{M}=$ molecular marker $1 \mathrm{~kb}$ Plus Ladder (Qiagen, Hilden, Germany); $1=$ Aspergillus flavus 8959; $2=$ Aspergillus oryzae var. effusus 8976; $3=$ A. oryzae var. effusus $8931 / 1 ; 4=$ A. flavus $8931 / 2 ; 5=$ A. flavus $8931 / 3 ; 6=$ A. oryzae var. effusus $8931 / 4 ; 7=A$. oryzae var. effusus $8931 / 5 ; 8=A$. oryzae var. effusus $8931 / 6$; $9=$ A. flavus $8931 / 7 ; 10=$ A. flavus $9002 ; 11=$ A. oryzae var. effusus $9004 ; 12=$ A. flavus $9005 ; 13=$ A. flavus $9006 ; 14=$ A. flavus $9010 ; 15$ $=$ A. flavus $9011 ; 16=$ A. flavus $9012 ; 17=$ A. flavus $9015 / 1 ; 18=$ A. flavus $9015 / 2 ; 19=A$. flavus $9015 / 3 ; 20=A$. flavus $9016 ; 21=$ negative control; $22=$ positive control. 
out of 14 strains of $A$. flavus showed the presence of the complete gene pattern and, of these strains, 6 were able to produce AF. According to Criseo et al. (2001), some atoxigenic strains could have a quadruplet pattern and other markers are necessary to discriminate aflatoxigenic strains from atoxigenic ones. Furthermore, the occurrence of S sclerotia was positively related to the production of $\mathrm{AF}$ in vitro, as previously reported by Cotty (1989). On the other hand, some A. flavus strains isolated from the corn silage in our study did not reveal the presence of the complete $\mathrm{AF}$ gene pattern and were unable to produce $\mathrm{AF}$ in vitro. This observation could be a starting point for future investigations on the selection of atoxigenic $A$. flavus to occupy the same niche as the naturally occurring epiphytic toxigenic $A$. flavus, as recently proposed as a strategy to reduce AF contamination in the field (Mauro et al., 2018).

During aerobic deterioration, the molds also degraded starch and part of the hemicelluloses, thus contributing to an increase of the less degradable part of NDF. This was previously described by Tabacco et al. (2011), who reported that when molds started to grow, the nutritional value of the silages decreased, with a strong reduction in the starch content, which represents the main energy component of corn silage, an increase in NDF, and a reduction in its degradability.

\section{CONCLUSIONS}

Ensiling corn that was naturally contaminated by aflatoxin did not change its aflatoxin concentration at the end of a long conservation period. Aspergillus flavus showed ability to survive in the anaerobic silage and revive when the inhibiting conditions in terms of low $\mathrm{pH}$ and temperature were lost. Both the control and inoculated silages deteriorated during aerobic exposure and showed an increase in the $A$. flavus count and $\mathrm{AFB}_{1}$ concentration. Inoculation with $\mathrm{LB}$ and $\mathrm{LB}+\mathrm{LH}$ increased the aerobic stability of the silages and delayed the onset of aerobic microbial degradation, this, in turn, could indirectly reduce the risk of A. flavus outgrowth and $\mathrm{AFB}_{1}$ production after silage opening.

\section{ACKNOWLEDGMENTS}

Mention of trade names or commercial products in this article is solely for the purpose of providing specific information, and does not imply either recommendation or endorsement by the University of Turin, Italy. This work was supported by Fondazione Cassa di Risparmio di Cuneo (CRC, Cuneo, Italy), Project "SOST-MILK- Plant health emergencies of corn and sustainability of the Piedmontese milk chain" Bando
Ricerca Scientifica 2015 and by a grant (Agreement 004036) from Danstar Ferment AG (Zug, Switzerland). The authors also thank Mauro and Luciano Comino (Lembo Farm S.S., Rocca de'Baldi, CN, Italy) for providing the corn silages used in this study; and Ilenia Siciliano (Agroinnova, University of Turin, Italy) for the help in characterization of A. flavus strains.

\section{REFERENCES}

Abbas, H. K., M. A. Weaver, R. M. Zablotowicz, B. W. Horn, and W. T. Shier. 2005. Relationships between aflatoxin production and sclerotia formation among isolates of Aspergillus section Flavi from the Mississippi Delta. Eur. J. Plant Pathol. 112:283-287.

Ahlberg, S. H., V. Joutsjoki, and H. J. Korhonen. 2015. Potential of lactic acid bacteria in aflatoxin risk mitigation. Int. J. Food Microbiol. 207:87-102.

Alonso, V. A., C. M. Pereyra, L. A. M. Keller, A. M. Dalcero, C. A. R. Rosa, S. M. Chiacchiera, and L. R. Cavaglieri. 2013. Fungi and mycotoxin in silage: An overview. J. Appl. Microbiol. 115:637-643.

AOAC International. 2005. Official Methods of Analysis. 18th ed. AOAC International, Gaithersburg, MD.

Arriola, K. G., S. C. Kim, and A. T. Adesogan. 2011. Effect of applying inoculants with heterolactic or homolactic and heterolactic bacteria on the fermentation and quality of corn silage. J. Dairy Sci. 94:1511-1516.

Assis, F. G. D., C. L. D. Avila, J. C. Pinto, and R. F. Schwan. 2014. New inoculants on maize silage fermentation. Rev. Bras. Zootec. 43:395-403.

Borreani, G., S. Piano, and E. Tabacco. 2014. Aerobic stability of maize silage stored under plastic films with different oxygen permeability. J. Sci. Food Agric. 94:2684-2690.

Borreani, G., and E. Tabacco. 2008. Low permeability to oxygen of a new barrier film prevents butyric acid bacteria spore formation in farm corn silage. J. Dairy Sci. 91:4272-4281.

Borreani, G., E. Tabacco, R. J. Schmidt, B. J. Holmes, and R. E. Muck. 2018. Silage review: Factors affecting dry matter and quality losses in silages. J. Dairy Sci. 101:3952-3979.

Canale, A., M. E. Valente, and A. Ciotti. 1984. Determination of volatile carboxylic acids (C1-C5) and lactic acid in aqueous acid extracts of silage by high performance liquid chromatography. J. Sci. Food Agric. 35:1178-1182.

Carvalho, B. F., C. L. S. Avila, P. M. Krempser, L. R. Batista, M. N. Pereira, and R. F. Schwan. 2016. Occurrence of mycotoxins and yeasts and moulds identification in corn silages in tropical climate. J. Appl. Microbiol. 120:1181-1192.

Cavallarin, L., E. Tabacco, S. Antoniazzi, and G. Borreani. 2011. Aflatoxin accumulation in whole crop maize silage as a result of aerobic exposure. J. Sci. Food Agric. 91:2419-2425.

Cheli, F., A. Campagnoli, and V. Dell'Orto. 2013. Fungal populations and mycotoxins in silages: From occurrence to analysis. Anim. Feed Sci. Technol. 183:1-16.

Comino, L., E. Tabacco, F. Righi, A. Revello-Chion, A. Quarantelli, and G. Borreani. 2014. Effects of an inoculant containing a Lactobacillus buchneri that produces ferulate-esterase on fermentation products, aerobic stability, and fibre digestibility of maize silage harvested at different stages of maturity. Anim. Feed Sci. Technol. 198:94-106.

Cotty, P. J. 1989. Virulence and cultural characteristics of two Aspergillus flavus strains pathogenic on cotton. Phytopathology 79:808-814.

Criseo, G., A. Bagnara, and G. Bisignano. 2001. Differentiation of aflatoxin-producing and non-producing strains of Aspergillus flavus group. Lett. Appl. Microbiol. 33:291-295.

Criseo, G., C. Racco, and O. Romeo. 2008. High genetic variability in non-aflatoxigenic A. flavus strains by using Quadruplex PCRbased assay. Int. J. Food Microbiol. 125:341-343. 
Decastelli, L., J. Lai, M. Gramaglia, A. Monaco, C. Nachtmann, F. Oldano, M. Ruffier, A. Sezian, and C. Bandirola. 2007. Aflatoxins occurrence in milk and feed in Northern Italy during 2004-2005. Food Control 18:1263-1266.

Driehuis, F. 2013. Silage and the safety and quality of dairy foods: A review. Agric. Food Sci. 22:16-34.

Driehuis, F., M. C. Spanjer, J. M. Scholten, and M. C. Te Giffel. 2008. Occurrence of mycotoxins in maize, grass and wheat silage for dairy cattle in the Netherlands. Food Addit. Contam. Part B Surveill. 1:41-50.

DuBois, M., K. A. Gilles, J. K. Hamilton, P. A. Rebers, and F. Smith. 1956. Colorimetric method for determination of sugars and related substances. Anal. Chem. 28:350-356.

el-Nezami, H., P. Kankaanpää, S. Salminen, and J. Ahokas. 1998. Physico-chemical alterations enhance the ability of dairy strains of lactic acid bacteria to remove aflatoxin from contaminated media. J. Food Prot. 61:466-468.

El-Shanawany, A. A., M. Eman Mostafa, and A. Barakat. 2005. Fungal populations and mycotoxins in silage in Assiut and Sohag governorates in Egypt, with a special reference to characteristic Aspergilli toxins. Mycopathologia 159:281-289.

Garon, D., E. Richard, L. Sage, V. Bouchart, D. Pottier, and P. Lebailly. 2006. Mycoflora and multimycotoxin detection in corn silages: Experimental study. J. Agric. Food Chem. 54:3479-3484.

González Pereyra, M. L., V. A. Alonso, R. Sager, M. B. Morlaco, C. E. Magnoli, A. L. Astoreca, C. A. daRosa, S. M. Chiacchiera, A M. Dalcero, and L. R. Cavaglieri. 2008. Fungi and select mycotoxins from pre- and post- fermented corn silage. J. Appl. Microbiol. 104:1034-1041.

Guo, B., Z. Y. Chen, R. D. Lee, and B. T. Scully. 2008. Drought stress and preharvest aflatoxin contamination in agricultural commodity: genetics, genomics and proteomics. J. Integr. Plant Biol. 50:1281-1291.

Hong, S. B., H. S. Cho, H. D. Shin, J. C. Frisvad, and R. A. Samson. 2006. Novel Neosartorya species isolated from soil in Korea. Int. J. Syst. Evol. Microbiol. 56:477-486.

Horn, B. W. 2003. Ecology and population biology of aflatoxigenic fungi in soil. J. Toxicol. Toxin Rev. 22:355-383.

Horn, B. W., and J. W. Dorner. 1998. Soil populations of Aspergillus species from section Flavi along a transect through peanut-growing regions of the United States. Mycologia 90:767-776.

Horn, B. W., R. L. Greene, V. S. Sobolev, J. W. Dorner, J. H. Powell, and R. C. Layton. 1996. Association of morphology and mycotoxin production with vegetative compatibility groups in A. flavus, A parasiticus, and A. tamarii. Mycologia 88:574-587.

Iglesias, C., A. Bach, M. Devant, C. Adelantado, and M. A. Calvo. 2005. The effect of Lactobacillus buchneri inoculation on corn silages conservation. Pages 611-613 in Proc. XI Jornadas sobre Producción Animal. Gobierno de Aragón, Servicio de Investigación Agroalimentaria, Zaragoza, Spain.

IRAC. 2012. Agents Classified by the IRAC Monograph. Vol. 1 and 104. International Agency for Research on Cancer. Accessed Mar. 05, 2018. http://monographs.iarc.fr/ENG/Classification/index php.

Keller, L. A. M., M. L. González Pereyra, K. M. Keller, V. A. Alonso, A. A. Oliveira, T. X. Almeida, T. S. Barbosa, L. M. T. Nunes, L. R. Cavaglieri, and C. A. R. Rosa. 2013. Fungal and mycotoxins contamination in corn silage: monitoring risk before and after fermentation. J. Stored Prod. Res. 52:42-47.

Kleinschmit, D. H., and L. Kung Jr. 2006. A meta-analysis of the effects of Lactobacillus buchneri on the fermentation and aerobic stability of corn and grass and small-grain silages. J. Dairy Sci. 89:4005-4013.

Lacey, J. 1989. Pre- and post-harvest ecology of fungi causing spoilage of food and other stored products. J. Appl. Bacteriol. Sym. 1989(Suppl. 67):11-25. https://doi.org/10.1111/j.1365-2672.1989 .tb03766.x.

Ma, Z. X., F. X. Amaro, J. J. Romero, O. G. Pereira, K. C. Jeong, and A. T. Adesogan. 2017. The capacity of silage inoculant bacteria to bind aflatoxin $\mathrm{B}_{1}$ in vitro and in artificially contaminated corn silage. J. Dairy Sci. 100:7198-7210.

Mauro, A., P. Battilani, K. A. Callicott, P. Giorni, A. Pietri, and P. J. Cotty. 2013. Structure of an Aspergillus flavus population from maize kernels in northern Italy. Int. J. Food Microbiol. 162:1-7.

Mauro, A., E. Garcia-Cela, A. Pietri, P. J. Cotty, and P. Battilani 2018. Biological control products for aflatoxin prevention in Italy: commercial field evaluation of atoxigenic Aspergillus flavus active ingredients. Toxins (Basel) 10:30.

Mitchell, N. J., E. Bowers, C. Hurburgh, and F. Wu. 2016. Potential economic losses to the US corn industry from aflatoxin contamination. Food Addit. Contam. A Chem. Anal. Control Expo. Risk Assess. 33:540-550

Muck, R. E., E. M. G. Nadeau, T. A. McAllister, F. E. ContrerasGovea, M. C. Santos, and L. Kung Jr. 2018. Silage review: Recent advances and future uses of silage additives. J. Dairy Sci. 101:3980-4000.

Murphy, P. A., S. Hendrich, C. Landgren, and C. M. Bryant. 2006. Food mycotoxins: An update. J. Food Sci. 71:51-65.

Nesci, A., and M. Etcheverry. 2002. Aspergillus section Flavi populations from field maize in Argentina. Lett. Appl. Microbiol. 34:343348.

Ogunade, I. M., C. Martinez-Tuppia, O. C. M. Queiroz, Y. Jiang, P. Drouin, F. Wu, D. Vyas, and A. T. Adesogan. 2018. Silage review: Mycotoxins in silage: Occurrence, effects, prevention, and mitigation. J. Dairy Sci. 101:4034-4059.

Oluwafemi, F., M. Kumar, R. Bandyopadhyay, T. Ogunbanwo, and K. B. Ayanwande. 2010. Biol.-detoxification of aflatoxin B1 in artificially contaminated maize grains using lactic acid bacteria. Toxin Rev. 29:115-122.

Oude Elferink, S. J. W. H., J. Krooneman, J. C. Gottschal, S. F Spoelstra, F. Faber, and F. Driehuis. 2001. Anaerobic conversion of lactic acid to acetic acid and 1,2-propanediol by Lactobacillus buchneri. Appl. Environ. Microbiol. 67:125-132.

Pahlow, G., R. E. Muck, F. Driehuis, S. J. W. H. Oude Elferink, and S. F. Spoelstra. 2003. Microbiology of ensiling. Pages 31-93 in Silage Science and Technology (Agronomy Series No. 42). Buxton D. R., R. E. Muck, and H. J. Harrison, ed. American Society of Agronomy, Madison, WI.

Playne, M. J., and P. McDonald. 1966. The buffering constituents of herbage and of silage. J. Sci. Food Agric. 17:264-268.

Porter, M. G., and R. S. Murray. 2001. The volatility of components of grass silage on oven drying and the inter-relationship between drymatter content estimated by different analytical methods. Grass Forage Sci. 56:405-411.

Prencipe, S., I. Siciliano, C. Contessa, R. Botta, A. Garibaldi, M. L. Gullino, and D. Spadaro. 2018. Characterization of Aspergillus section Flavi isolated from fresh chestnuts and the chestnut flour process. Food Microbiol. 69:159-169.

Queiroz, O. C. M., S. C. Kim, and A. T. Adesogan. 2012. Effect of treatment with a mixture of bacteria and fibrolytic enzymes on the quality and safety of corn silage infested with different levels of rust. J. Dairy Sci. 95:5285-5291.

Richard, E., N. Heutte, V. Bouchart, and D. Garon. 2009. Evaluation of fungal contamination and mycotoxin production in maize silage. Anim. Feed Sci. Technol. 148:309-320.

Richard, E., N. Heutte, L. Sage, D. Pottier, V. Bouchart, P. Lebailly, and D. Garon. 2007. Toxigenic fungi and mycotoxins in mature corn silage. Food Chem. Toxicol. 45:2420-2425.

Robertson, J. B., and P. J. Van Soest. 1981. The detergent system of analysis and its application to human foods. Pages 123-158 in The Analysis of Dietary Fiber in Food. W. P. T. James and O. Theander, ed. Marcel Dekker, New York, NY.

Rosiles, R. M. 1978. Estudio de las Aflatoxinas en ensilado de maiz. (A study of aflatoxins in ensiled corn.). Veterinaria (Mex.) 9:163-167.

Samson, R. A., E. S. Hoekstra, and J. C. Frisvad. 2004. Introduction to food and airborne fungi. 7th ed. Centraalbureau voor Schimmelcultures (CBS), Utrecht, the Netherlands. 
Samson, R. A., C. M. Visagie, and J. Houbraken. 2014. Phylogeny, identification and nomenclature of the genus Aspergillus. Stud. Mycol. 78:141-173.

Spadaro, D., M. P. Bustos-Lopez, M. L. Gullino, S. Piano, E. Tabacco, and G. Borreani. 2015. Evolution of fungal population in corn silage conserved under polyethylene or biodegradable films. J. Appl. Microbiol. 119:510-520.

Spoelstra, S. F., M. G. Courtin, and J. A. C. van Beers. 1988. Acetic acid bacteria can initiate aerobic deterioration of whole crop maize silage. J. Agric. Sci. 111:127-132.

Tabacco, E., F. Righi, A. Quarantelli, and G. Borreani. 2011. Dry matter and nutritional losses during aerobic deterioration of corn and sorghum silages as influenced by different lactic acid bacteria inocula. J. Dairy Sci. 94:1409-1419.

Van Soest, P. J., J. B. Robertson, and B. A. Lewis. 1991. Methods of dietary fiber, neutral detergent fiber, and nonstarch polysaccharides in relation to animal nutrition. J. Dairy Sci. 74:3583-3597.
Varga, J., J. C. Frisvad, and R. A. Samson. 2011. Two new aflatoxin producing species, and an overview of Aspergillus section Flavi. Stud. Mycol. 69:57-80.

Veldman, A., J. A. C. Meijst, G. J. Borggreve, and J. J. Heeres-van der Tol. 1992. Carry-over of aflatoxin from cows'food to milk. Anim. Prod. 55:163-168.

Visagie, C. M., Y. Hirooka, J. B. Tanney, E. Whitfield, K. Mwangen, M. Meijer, A. S. Amend, K. A. Seifert, and R. A. Samson. 2014. Aspergillus, Penicillium and Talaromyces isolated from house dust samples collected around the world. Stud. Mycol. 78:63-139.

Weinberg, Z. G., Y. Chen, and R. Solomon. 2009. The quality of commercial wheat silages in Israel. J. Dairy Sci. 92:638-644.

World Health Organization, 2002. Report on meetings of expert committees and study groups. WHO Technical Report Series, No. 906 Accessed Dec. 3, 2018. http://apps.who.int/gb/archive/pdf_files/ eb110/eeb1106.pdf. 